\title{
Sector Heterogeneity and Credit Market Imperfections in Emerging Markets
}

July 2016

\begin{abstract}
This paper shows that the impact of country interest rate shocks on emerging markets' economic activities can be associated with credit market imperfections affecting principally non-tradable activities. I present novel evidence documenting that tradable and non-tradable activities respond asymmetrically to changes in credit conditions in emerging markets. I show that country interest rate shocks are amplified through non-tradable activities, and that local credit substantially explains their output growth. Unlike the non-tradable sector, tradable activities are not significantly affected by changes in local credit conditions. To rationalize these findings, I introduce a small open economy model with heterogenous access to international borrowing that accounts for the asymmetric response of tradable and non-tradable activities.
\end{abstract}

Keywords: financial frictions, interest rate shocks, emerging markets. JEL: E44, F34, F41, F43. 


\section{Introduction}

External shocks substantially aggregate activities in emerging markets. Changes in international terms of trade, sudden stops of capital inflows, and interest rate shocks have been at the center of economic downturns in these countries over the last decades. ${ }^{1}$ In particular, several studies show that interest rate shocks explain a non-negligible part of declines in aggregate activities in these emerging markets, and that financial frictions are critical in the propagation of these shocks (Uribe and Yue 2006, Chang and Fernandez 2013, Tornell and Westermann (2005), among others).

This paper shows that increases in the cost of borrowing propagate asymmetrically across sectors in emerging markets. I present novel evidence documenting that country interest rate shocks are negatively correlated with output in non-tradable activities, whilst present no significant relationship with tradable activities. Additionally, I demonstrate that this differential response of non-tradable activities relates to their higher dependence on domestic credit. Importantly, this greater countercyclical co-movement between interest rate and non-tradable output is at odds with the standard small open economy model, in which interest rate shocks affect the tradable capital-intensive sector the most. To rationalize the negative response of non-tradable output, I develop a small open economy model and show that asymmetries in the access to external finance can account for the distinctive and a priori counterintuitive response across sectors. The greater downturn of non-tradable activities can be explained by their higher reliance on domestic credit and, hence, by their deeper exposure to local financial frictions.

A well-documented fact in international economics is that the interest rate is countercyclical in emerging markets, but a-cyclical in developed open economies (Uribe and Yue 2006; and Neumeyer and Perri 2005). Table 1 reproduces these relationships for a group of twenty emerging markets and fifteen developed open economies for the period between 1990q1 and 2015q4. Column 1 shows that increases in the domestic borrowing cost are associated with declines in emerging markets' activities, while they are unrelated to output fluctuations in developed open economies. What drives the economic downturn in emerging markets? The decomposition between tradable and non-tradable activities is revealing: the observed declines are related to downturns in the non-tradable sector

\footnotetext{
${ }^{1}$ For instance, Calvo, Leiderman, and Reinhart (1993) report that the U.S. interest rate was a major determinant of the economic expansion of Latin American countries in the early 1990s. Calvo, Izquierdo, and Mejía (2004) show that sudden stops are associated with financial disruptions, exchange rate depreciations, and economic recessions. Several studies point out that changes in the terms of trade explain a non-negligible part of output drops in developing economies (for example Mendoza 1995; Kose 2002; and Broda 2004). Canova (2005) shows that U.S. interest rate shocks negatively correlate with output fluctuations in Latin American countries. Blankenau, Kose, and Yi (2001) find that world interest rate play an important role in explaining variations in output, export and net foreign assets in small open economies.
} 
Table 1: Panel VAR: Country Interest Rate and Output Growth

\begin{tabular}{|c|c|c|c|}
\hline \multirow[b]{3}{*}{ Interest rate } & \multicolumn{3}{|c|}{ Output Growth } \\
\hline & \multirow{2}{*}{$\frac{\overline{G D P}}{(1)}$} & \multirow{2}{*}{$\frac{\text { Tradable }}{(2)}$} & \multirow{2}{*}{$\begin{array}{l}\text { Non-Tradable } \\
(3)\end{array}$} \\
\hline & & & \\
\hline Emerging Markets & $\begin{array}{l}-0.067^{* *} \\
(0.028)\end{array}$ & $\begin{array}{l}-0.059 \\
(0.054)\end{array}$ & $\begin{array}{l}-0.064^{* *} \\
(0.031)\end{array}$ \\
\hline Developed Open Economies & $\begin{array}{c}-0.031 \\
(0.262)\end{array}$ & $\begin{array}{l}0.391 \\
(0.286)\end{array}$ & $\begin{array}{l}-0.146 \\
(0.265)\end{array}$ \\
\hline \multicolumn{4}{|c|}{$\begin{array}{l}\text { Notes: standard errors in parenthesis. ***,*** significant at } 10 \%, 5 \%, 1 \% \text {, respectively. Period: 1990q1: } \\
\text { 2015q5. The real interest rate for developed small open economies is the short-term 3-month interest } \\
\text { rate from MEI-OECD; the real interest rate for emerging markets is computed as the U.S. Tbill + EMBI } \\
\text { GLOBAL. EMs: Argentina, Brazil, Bulgaria, Chile, Czech Republic, Hungary, Indonesia, Iran, Korea, } \\
\text { Malaysia, Mexico, Nigeria, Peru, Philippines, South Africa, Taiwan, Thailand, Tunisia, Turkey and Ukraine. } \\
\text { DOEs: Australia, Austria, Belgium, Canada, Denmark, Finland, France, Ireland, Italy, Netherlands, Norway, } \\
\text { Portugal, Spain, Sweden, and Switzerland. }\end{array}$} \\
\hline
\end{tabular}

(columns 2 and 3). A one percentage point increase in the country interest rate associates with a $6.4 \%$ decline of non-tradable output, whereas this relationship is not significant for the tradable sector. Remarkably, this differential response of the non-tradable sector is absent in developed open economies. As Table 1 shows, the correlation between the cost of borrowing and non-tradable output vanishes in developed open economies.

The larger impact of the borrowing cost on non-tradable activities is remarkable, as these activities are labor-intensive. This paper sustains that the greater exposure of nontradable firms to domestic credit market imperfections can account for this feature. To rationalize this argument, I use a textbook small open economy model and add asymmetries in the access to international borrowing. In the model, agents face heterogeneous access to credit depending on the enforceability of debt contracts (as in Eaton and Gersovitz 1981; Kletzer and Bardhan 1987; and Arellano, Bai, and Zhang 2012, among others). Tradable firms have perfect access to international capital markets, as foreign lenders find it easy to enforce their debt contracts by submitting them to foreign courts. Non-tradable firms are instead subject to financial imperfections, as there is no international authority that can enforce their debt contracts. In this context, foreign lenders face the risk of debt repudiation and charge a risk premium based on non-tradable firms' default probability. This default probability is endogenously determined and increases with the level of debt repayment. In this way, an increase in the interest rate leads to a larger increase in non-tradable firms' borrowing costs, as it also raises their debt repayments and default probability. It is the exposure to financial frictions that non-tradable firms face what leads 
to a deeper downturn in their activities.

I next turn to the empirics and assess the relationship between financing terms and output growth in two steps. I first estimate a panel VAR, the impulse response functions, and the variance decomposition for output growth to domestic and foreign interest rate shocks for a set of thirty-five economies (fifteen developed open economies and twenty emerging markets) at a quarterly frequency over the period 1990q1-2015q4, and next evaluate the relationship between domestic credit and output growth at sector level for emerging markets.

The empirical results show, first, that one percent increase in the domestic interest rate leads to a 7\% decrease in emerging markets' GDP. Second, non-tradable and tradable activities respond asymmetrically to domestic interest rate shocks. One percent increase in the domestic interest rate induces a $6.5 \%$ decline in non-tradable output, while it has nonsignificant effect on tradable activities. Notably, these results are driven by the increase in the country risk premium, as U.S. interest rate shocks show non-significant impact on emerging markets' GDP and non-tradable output. Third, the variance decomposition analysis demonstrates that domestic interest rate shocks have a substantial impact on emerging markets' business cycles, as they account for $14 \%$ of GDP fluctuations within business cycle frequency (20 quarters). Fourth, the variance decomposition analysis also reveals asymmetries in the source of fluctuations between tradable and non-tradable activities, as domestic interest rate shocks account for larger declines in non-tradable output. Fifth, these distinctive features observed in emerging markets following interest rate shocks are absent in developed small open economies. Finally, I construct a database on local credit and output at a quarterly frequency for tradable and non-tradable activities for emerging markets, and estimate a dynamic heterogeneous panel at sector level. Empirical results show that non-tradable activities are more reliant on the domestic credit market and, hence, more likely to be affected by local financial imperfections. I show that these results are robust to considering different identification assumptions for the VAR analysis -as long-term structural VAR and generalized impulse restrictions- as well as different characterization of non-tradable activities.

This paper adds to a long literature on the causes of economic downturns in emerging markets. In particular, studies on business cycles highlight the role of interest rate shocks on aggregate fluctuations in these economies (Neumeyer and Perri 2005; Uribe and Yue 2006; Tornell and Westermann 2005; and Chang and Fernandez 2013). I advance this literature by analyzing the propagation mechanism of these shocks, and demonstrating -for the first time- that the negative correlation between the interest rate and GDP growth stems from the drop of non-tradable output. This paper is closest to Tornell and Westermann (2005) who estimate VARs and show that country spread shocks correlate 
with drops in the ratio of tradable-to-non-tradable output in a group of emerging markets. This paper departs from Tornell and Westermann (2005) in that I separately identify the output responses of tradable and non-tradable sectors face to country and U.S. interest rate shocks, compute the forecast-error variance decomposition of these shocks across sectors, and use different VAR techniques to identify these shocks. Additionally, this paper extends the time and country coverage, allowing to generalize previous results. Importantly, the extension of time period shows that the negative impact of country interest rate shocks on aggregate fluctuations was not specific of the high volatility of emerging markets during the 1990s, but a permanent feature of these economies present over the last three decades. The extension of the sample to a broader set of emerging markets and developed economies confirms that the negative and distinctive response of GDP to domestic interest rate shocks is characteristics of emerging markets.

The higher dependence of non-tradable activities on the domestic credit market is supported by micro-level studies demonstrating that non-tradable firms face more financial frictions than tradable firms. Tornell and Westermann (2005) report first evidence about the presence of asymmetries of financing opportunities between tradable and non-tradable firms in middle-income countries. Their results document that tradable firms have easier access to external finance because they can pledge export receivables as collateral and can receive guarantees from closely links firms. By contrast, non-tradable firms are smaller and face tighter borrowing constraints. ${ }^{2}$ This paper is complementary to Tornell and Westermann (2005) insofar as I provide a more comprehensive analysis of the relationship between domestic credit conditions and sectoral output growth in emerging markets.

The remainder of the paper is structured as follows. Section 2 presents a small open economy model with international borrowing to rationalize the response of tradable and non-tradable sectors to interest rate shocks. In Section 3, I assess empirically these responses in two steps. First, I document the sectoral output responses to domestic and foreign interest rates shocks, the impulse response functions, and the variance decomposition analysis for emerging markets and developed small open economies. Second, I estimate a dynamic heterogeneous panel of credit and output at sector level in emerging markets. The last section concludes.

\footnotetext{
${ }^{2}$ In a similar vein, there is a line of literature showing that firms involved in international trade have better access to the international capital markets (see for example Alfaro, Chari, and Kanczuk 2016; and WorldBank 2004).
} 


\section{A SOE Model with Asymmetric Access to Finance}

The standard small open economy (SOE) model states that increases in the borrowing cost affect the capital-intensive tradable sector the most. However, as shown in the introduction, interest rate shocks greatly correlate with output drops in the labor-intensive non-tradable sector. In this section, I use a SOE model with international borrowing to show that the presence of heterogeneous access to external finance can explain the empirical patterns observed in the data.

\section{The Standard SOE Model}

To assess the impact of interest rate shocks on output, consider the textbook small open economy model where the economy is composed by two goods: tradable and nontradable, and two factors of production: capital and labour. Assume that the tradable and non-tradable sectors are perfectly competitive, and the representative firm operates with a Cobb-Douglas function: $Y_{t}^{i}=K_{t}^{i \alpha_{i}} L_{t}^{i 1-\alpha_{i}}$, where i=Tradable, Non-tradable. Let $\alpha_{T}>\alpha_{N}$, i.e. the tradable sector is capital-intensive and the non-tradable sector is labor-intensive. Perfect capital mobility and financial markets ensure that rates of return equalize across countries and sectors in equilibrium, and capital adjusts until its marginal product equalizes the foreign interest rate.

In this setting, a foreign interest rate shock reduces the tradable output the most, as it affects more the sector using capital more intensively. To see this, consider the elasticity of tradable and non-tradable output to changes in the foreign interest rate $\left(R^{*}\right)$,

$$
\epsilon_{y_{t}^{T}, R_{t}^{*}}=-\frac{\alpha^{T}}{1-\alpha^{T}} \quad \text { and } \quad \epsilon_{y_{t}^{N}, R_{t}^{*}}=-\frac{\alpha^{N}}{1-\alpha^{T}}
$$

As $\alpha^{T}>\alpha^{N}$, an unexpected shock in the foreign interest rate leads to a larger decrease in the tradable output.

\section{Credit Market Imperfections}

There is a broad consensus in the economic literature that credit markets are subject to non-negligible financial frictions in emerging markets. To model these frictions, many economists have focused on enforcement problems to debt contracts (see for example Eaton and Gersovitz 1981; Kletzer and Bardhan 1987; and Arellano, Bai, and Zhang 2012). This paper follows this approach and let borrowers face differential access to credit markets depending on how debt contracts can be enforced. In particular, since tradable firms' 
activity is oriented to foreign markets, lenders may find easy to enforce debt contracts with these firms by submitting them to foreign courts. Conversely, as there is no external authority that guarantees that non-tradable firms fulfill their debt obligations, foreign creditors face the risk of debt repudiation from non-tradable firms. To microfound debt contracts to non-tradable firms, I follow Eaton and Gersovitz (1981) and let the risk neutral foreign lenders impose a penalty that the non-tradable firm suffers if she defaults on her debt obligation. The penalty, $\theta k_{t+1}^{N}$, is a fraction of capital in the non-tradable sector, where $\theta$ is stochastic and follows an exponential distribution supported on the interval $[0, \infty)$, i.e. $\theta \operatorname{Exp}(\lambda)$. The borrower repays its obligation whenever the penalty is higher than the amount of debt times the interest she has to pay, $\theta k_{t+1}^{N} \geq R_{t} d_{t+1}^{N}$, and defaults in the opposite case. The default probability is defined as follows: $\Gamma_{t}=\operatorname{Pr}\left(\theta k_{t+1}^{N}<\right.$ $R_{t} d_{t+1}^{N}$ ), where $R$ denotes the domestic interest rate, and the probability of default $\Gamma$ is endogenously determined and increasing in the level of debt repayment $\left(F^{\prime}()>0.\right)$.

The equilibrium in the financial market imposes the following arbitrage condition for the foreign investor: $R_{t}=\frac{1}{1-\Gamma_{t}} R_{t}^{*}$. This condition defines the supply curve for new capital for the non-tradable sector. This supply curve is upward sloping and depends on amount due by the non-tradable firm. As larger is the debt repayment of the non-tradable firm, higher are its opportunity cost of default and its risk-premium. Notice that, as the tradable firm is not subject to enforcement problems, its supply curve for new capital is perfectly elastic and horizontal at the world level interest rate.

In the presence of financial frictions, the impact of the foreign interest rate shock differs from the standard case. To see this, consider firms' elasticities to the foreign interest rate:

$$
\epsilon_{y_{t}^{T}, R_{t}^{*}}=-\frac{\alpha^{T}}{1-\alpha^{T}} \quad \text { and } \quad \epsilon_{y_{t}^{N}, R_{t}^{*}}=-\left[\frac{\alpha^{N} \alpha^{T}}{1-\alpha^{T}}+\alpha^{N} \epsilon_{R, R_{t}^{*}}\right],
$$

where $\epsilon_{R, R_{t}^{*}}$ is the elasticity of domestic to the foreign interest rate and is bigger than one. Notice that the output elasticity of the tradable firm remains unchanged, whilst the elasticity in the non-tradable firm is augmented by the impact of the initial shock on the domestic interest rate. In particular, the increase in the international borrowing cost raises the debt burden, and with it the default probability and the interest rate perceived by the non-tradable firm. In this way, the foreign interest rate shock is amplified through the presence of local financial imperfection on the non-tradable firm. Equation (2) shows that a foreign interest rate shock has a larger negative impact on the output of the non-tradable sector as it increases the risk premium that this sector pays. Therefore, differences in the level of contract enforceability across sectors imply different co-movements between sectoral outputs and the domestic interest rate, as stated in the following proposition. 
Proposition: In presence of credit market imperfections, non-tradable output is negatively correlated with the domestic interest rate, whilst tradable output is uncorrelated. It is the increase in the domestic risk premium affecting non-tradable firms what accounts for this asymmetric response across sectors.

Proof: this follows directly from equation (2).

In sum, asymmetries in contract enforceability can substantially affect non-tradable firms as they differentially affect their financing terms. Interest rate shocks raise the debt repayment, which increases the default probability and risk premium, amplifying the impact of the initial shock. In the next section, I test this result against the data.

\section{Empirical Analysis}

This section studies tradable and non-tradable output responses to changes in financing terms. Section 3.1 introduces the data. Section 3.2 analyzes the sectoral output responses to domestic and foreign interest rate shocks for a group of emerging markets and developed open economies. Section 3.3 assesses the domestic credit and output dynamic relationship at sector level for emerging markets.

\subsection{Data}

To study the sectoral output responses to interest rate shocks, I construct a sample of thirty-five countries: fifteen developed open economies (Australia, Austria, Belgium, Canada, Denmark, Finland, France, Ireland, Italy, Netherlands, Norway, Portugal, Spain, Sweden and Switzerland) and twenty emerging markets (Argentina, Brazil, Bulgaria, Chile, Czech Republic, Hungary, Indonesia, Iran, Korea, Malaysia, Mexico, Nigeria, Peru, Philippines, South Africa, Taiwan, Thailand, Tunisia, Turkey and Ukraine) for the period 1990q1 to 2015q4. The sample of emerging markets consists of countries included in the Emerging Markets Bond Index (EMBI) and that report output data by economic activity at quarterly frequency. Sectoral output data is obtained from the National Statistical Office of each country (see Appendix $\mathrm{C}$ for further details). I consider tradable activities as: agriculture, fishing, mining and manufacturing; and non-tradable activities as: utilities (electricity, gas and water supply), construction, wholesale and retail trade, transportation, hotels and food services activities, information and communication, financial and real estate activities, professional activities, public administration, education, health, arts 
and other services. These activities follow the NACE Rev 2 classification at one digit level. Additionally, I undertake two sensitivity analysis for non-tradable activities. I first exclude from the sample finance and real estate activities, and turn next to also exclude government regulated activities, as utilities, public administration, education and health. The interest rate for open economies is the 3-month interest rate reported by OECD Stats. For emerging markets, I follow Uribe and Yue (2006) and Neumeyer and Perri (2005), and build the domestic interest rate as the sum of the risk free interest rate (3 months U.S. Treasury bill rate) and the risk premium (J.P. Morgan EMBI Global). Output values at producer prices are in U.S. dollars, and real terms are obtained by deflating the series with the U.S. GDP deflator provided by FRED St. Louis Fed.

To estimate the dynamic relationship between sectoral output and credit for emerging markets, I use credit data by economic activities for sixteen emerging markets (Argentina, Brazil, Bulgaria, Chile, Czech Republic, Hungary, Indonesia, Iran, Korea, Mexico, Peru, Philippines, Taiwan, Thailand, Turkey and Ukraine) for the period 1992q1 to 2015q4. ${ }^{3}$ Credit data is provided by the Central Bank of each country (see Appendix C for further details). Real terms are obtained by deflating series with the U.S. GDP deflator provided by FRED St. Louis Fed. Data on exports, imports and exchange rate comes from the IFS Statistics of the IMF. As in Tornell and Westermann (2005), the real exchange rate is computed as the ratio of the producer price and consumer price indexes, which are obtained form the IFS Statistics of the IMF. Data from crisis in emerging economies comes from Kaminsky (2006) and Reinhart and Rogoff (2010).

\subsection{Output Responses to Interest Rate Shocks}

This section analyzes the dynamic relationship between sectoral output and interest rates for emerging markets, and compare them with developed open economies. I start by employing panel VARs on tradable and non-tradable output growth, and the domestic and foreign interest rates. I turn next to study the impulse response functions of sectoral output growth to interest rate shocks. I perform later a variance decomposition analysis in order to identify the contribution of the different shocks to the output growth of each sector. Finally, I test whether results are robust to different VAR specifications, and classification of sectors.

\footnotetext{
${ }^{3}$ Unfortunately, some emerging markets do not report information of credit by economic activities at quarterly frequency.
} 


\subsubsection{Panel VAR}

I start by examining sectoral output responses to changes in the borrowing costs. Based on the model's equations (2), I estimate a panel VAR of output on changes in the domestic and foreign interest rate, as follows:

$$
y_{(i, t)}=\alpha_{0}+\sum_{m=1}^{p-1} \alpha_{m} y_{(i, t-m)}+f_{(i)}+\epsilon_{(t)}
$$

where $i$ and $t$ denote country and time. The vector $y$ is composed by $\left\{R, R_{U S}\right.$, Output Growth $\}$ including country interest rate, U.S. interest rate, and output growth. Following specifications in equations (2), I estimate a different panel VAR for GDP, and tradable and non-tradable outputs.

Similar to Holtz-Eakin and Rosen (1988) and Love and Zicchino (2006), the empirical model allows for country individual heterogeneity using a forward mean-differencing, also referred as Helmert procedure. This methodology removes the mean of all future observations for each group. By preserving the orthogonality between the transformed variables and the lagged regressors, the procedure allows to use the lagged regressors as instruments, and to estimate the coefficients by GMM. To account for country specific characteristics, the model also includes country fixed effects $f_{(i)}$. Finally, $m$ represents the number of lags that are determined following the AIC and BIC criteria. Both criteria report four lags for the output of developed open economies and one lag for the emerging markets.

Table 2 columns 1-3 report the response of output growth to changes in the interest rate for emerging markets, and columns 4-6 for developed open economies. Column 1 shows that, in emerging markets, aggregate output responds negatively to changes in the country interest rate, as in Uribe and Yue (2006). The estimated coefficient implies that an increase of one percentage point in the country interest rate correlates with a $6.7 \%$ in GDP drop within a quarter. Instead, in developed open economies, aggregate output remains unaffected by changes in the domestic interest rate (column 4$).{ }^{4}$

In emerging markets, tradable and non-tradable sectors respond heterogeneously to country interest rate shocks. While tradable activities are not affected by these shocks, non-tradable activities report a significant drop. Column 2 shows that the coefficient for the tradable sector is statistically non-significant and present large standard errors. Unlike the tradable sector, column 3 indicates that one percentage point increase in the domestic interest rate correlates with a decrease of $6.4 \%$ in non-tradable output growth within a quarter. Interesting, in developed open economies tradable and non-tradable activities do not correlate with innovations in the domestic interest rate within a quarter (columns 4

\footnotetext{
${ }^{4}$ Tables in B.1- B.3 in Appendix B present all the coefficients estimated in the VAR system.
} 
Table 2: Panel VAR: Interest Rate and Output Growth

\begin{tabular}{|c|c|c|c|c|c|c|}
\hline & \multicolumn{3}{|c|}{ Emerging Markets } & \multicolumn{3}{|c|}{ Developed Open Economies } \\
\hline & \multirow{2}{*}{$\begin{array}{l}\text { GDP } \\
(1)\end{array}$} & \multirow{2}{*}{$\begin{array}{l}\text { Tradable } \\
(2)\end{array}$} & \multirow{2}{*}{$\begin{array}{l}\text { Non- } \\
\text { Tradable } \\
(3)\end{array}$} & \multirow{2}{*}{$\begin{array}{l}\text { GDP } \\
(4)\end{array}$} & \multirow{2}{*}{$\begin{array}{l}\text { Tradable } \\
(5)\end{array}$} & \multirow{2}{*}{$\begin{array}{l}\begin{array}{l}\text { Non- } \\
\text { Tradable }\end{array} \\
(6)\end{array}$} \\
\hline & & & & & & \\
\hline Interest Rate $(-1)$ & $\begin{array}{l}-0.067^{* *} \\
(0.028)\end{array}$ & $\begin{array}{l}-0.059 \\
(0.054)\end{array}$ & $\begin{array}{l}-0.064^{* *} \\
(0.031)\end{array}$ & $\begin{array}{l}-0.031 \\
(0.262)\end{array}$ & $\begin{array}{l}0.391 \\
(0.286)\end{array}$ & $\begin{array}{l}-0.146 \\
(0.265)\end{array}$ \\
\hline Interest Rate U.S. (-1) & $\begin{array}{l}-0.057 \\
(0.050)\end{array}$ & $\begin{array}{c}-0.080^{*} \\
(0.046)\end{array}$ & $\begin{array}{c}-0.055 \\
(0.060)\end{array}$ & $\begin{array}{l}0.635^{*} \\
(0.337)\end{array}$ & $\begin{array}{l}1.151^{* * *} \\
(0.391)\end{array}$ & $\begin{array}{l}0.523 \\
(0.331)\end{array}$ \\
\hline \multicolumn{7}{|c|}{$\begin{array}{l}\text { Notes: standard errors in parenthesis. }{ }^{* * *}, * * * \text { significant at } 10 \%, 5 \%, 1 \% \text {, respectively. Period: 1990q1: 2015q4. The real } \\
\text { interest rate for developed small open economies is the short-term 3-month interest rate from MEI-OECD; the real interest rate } \\
\text { for emerging markets is computed as the U.S. Tbill + EMBI GLOBAL. EMs: Argentina, Brazil, Bulgaria, Chile, Czech Republic, } \\
\text { Hungary, Indonesia, Iran, Korea, Malaysia, Mexico, Nigeria, Peru, Philippines, South Africa, Taiwan, Thailand, Tunisia, Turkey and } \\
\text { Ukraine. Number of observations for emerging markers: 1,186. DOEs: Australia, Austria, Belgium, Canada, Denmark, Finland, } \\
\text { France, Ireland, Italy, Netherlands, Norway, Portugal, Spain, Sweden, and Switzerland. Number of observations for developed open } \\
\text { economies: } 1,230 \text {. }\end{array}$} \\
\hline
\end{tabular}

and 5). In this way, results in Table 2 indicate that the economic downturn -observed in previous studies- following domestic interest rate shocks is only driven by the decline in non-tradable activities. Furthermore, this response is characteristic of emerging markets and absent in developed open economies.

Finally, it is worth noting on the coefficient for U.S. Treasury bill rate shocks in emerging markets. Column 2 indicates that an increase in the U.S. interest rate associates with a drop in the output in the tradable sector. This decrease is consistent with the predictions of the small open economy model presented in Section 2, in which -in absence of financial frictions- the capital-intensive tradable sector is more affected by increases in the borrowing cost. Instead, it is the presence of local financial imperfections in emerging markets which amplifies the initial increase in the borrowing costs and leads to a higher downturn in the non-tradable output, as reported in column 3.

\subsubsection{Impulse Response Functions}

I now turn to study the impulse response functions of sectoral output to interest rate shocks. To identify output responses, I follow a Cholesky decomposition where the VAR ordering follows \{Interest Rate, Sectoral Output Growth\}. The identifying assumption is that interest rate shocks affect sectoral output contemporaneously as well as with a lag, while sectoral outputs only affect the interest rate with a lag. That is, I consider the interest rate as the exogenous variable, and sectoral output as the endogenous variable, 
as Uribe and Yue (2006), Neumeyer and Perri (2005), or Tornell and Westermann (2005). This ordering finds support on Neumeyer and Perri (2005), who show that in emerging markets the domestic interest rate leads GDP growth by one quarter. Furthermore, it can be derived from the structural model of Tornell and Westermann (2005), based on the rationale that in emerging markets the interest rate is driven exogenously by changes in external markets and that the standard monetary instruments have little leeway in affecting output. Following this ordering, I consider changes in the U.S. interest rate to lead emerging economies' output by one quarter.

Figure 1 displays the impulse response functions of the VAR system in equation (3) to one percentage point increase in the domestic and U.S. interest rates for GDP and sectoral output in emerging markets. The effect of the domestic interest rate shock on GDP growth is negative and statistically significant, as indicated by the area comprising in the $95 \%$ confident interval generated by Monte Carlo simulations with 1,000 repetitions. More precisely, one percentage point increase in the domestic interest rate decreases GDP growth by $7 \%$ within a quarter. This decline reaches its maximum in the second quarter, when falls to $9 \%$. Albeit smaller, this drop is line with Uribe and Yue (2006) who find that an innovation in the country interest rate is responsible for about $15 \%$ of the decrease in GDP growth in seven developing economies over the period 1994q1 to 2001q4. ${ }^{5}$

Similar to Table 2, the responses of tradable and non-tradable output to unanticipated interest rate shocks are heterogeneous in emerging markets. While the impact of the domestic interest rate shock in the non-tradable sector is also negative and statistically significant, the effect on the non-tradable sector is non-significant. An innovation of the domestic interest rate decreases non-tradable output growth by $6.5 \%$ within a quarter, and $8 \%$ in the second quarter. In emerging markets, the response of GDP and non-tradable output to innovations in the U.S. interest rate are statistically non-significant, while is negative and marginally significant for the tradable sector. As above, the asymmetric response of tradable and non-tradable activities is absent in developed open economies. As shown in Figure 2, domestic interest rate shocks do not have a significant impact on sectoral outputs in developed open economies.

\footnotetext{
${ }^{5}$ The smaller response of GDP growth to domestic interest rate shocks is explained by the longer time frame of the present study (1990q1 to 2015q4). When restricting the analysis to the 1990 s -a period characterized by large volatility and several economic crisis in emerging markets- GDP responses to country interest rate shocks are much greater. During the 1990s in the sample of twenty emerging markets, an innovation in the country interest rate explains about $27 \%$ of the fluctuations in GDP growth. It is worth noting that the negative response of GDP growth to interest rate shocks in emerging markets was also present during the Great Recession. Albeit estimated with a small sample, an innovation in the domestic interest rate correlates with a decline of one third of GDP growth in emerging markets between 2008q3 and $2011 \mathrm{q} 4$.
} 
Output Responses to a Domestic Interest Rate Shock
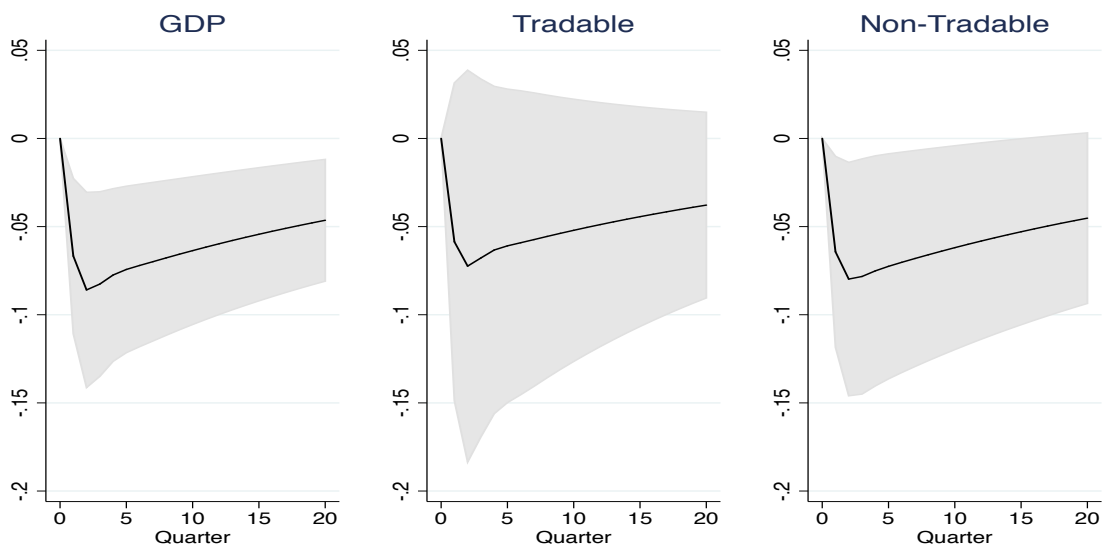

Output Responses to a US Interest Rate Shock
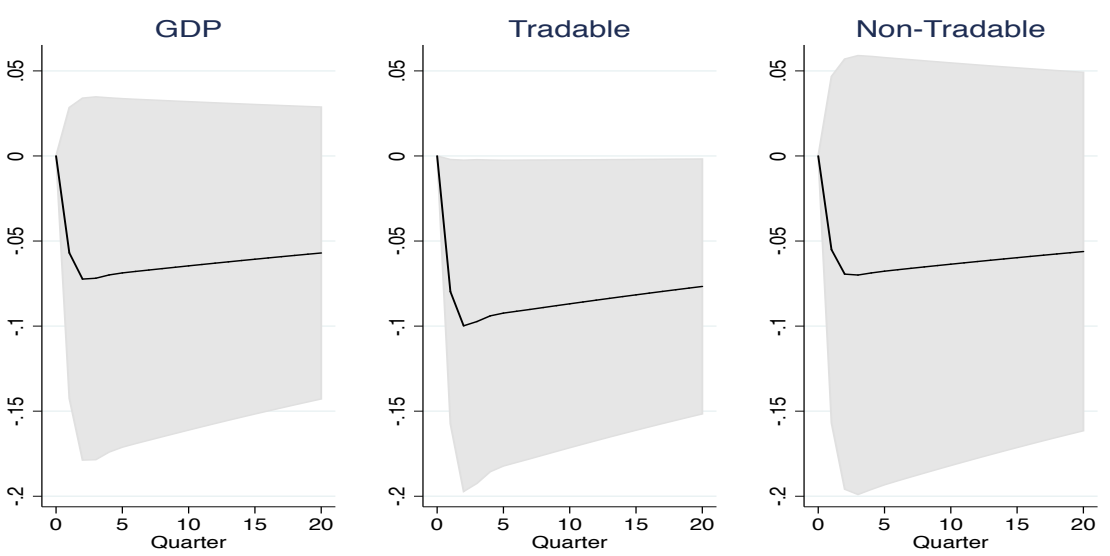

Figure 1: Emerging Markets: IRFs to Interest Rate Shocks 
Output Responses to a Domestic Interest Rate Shock
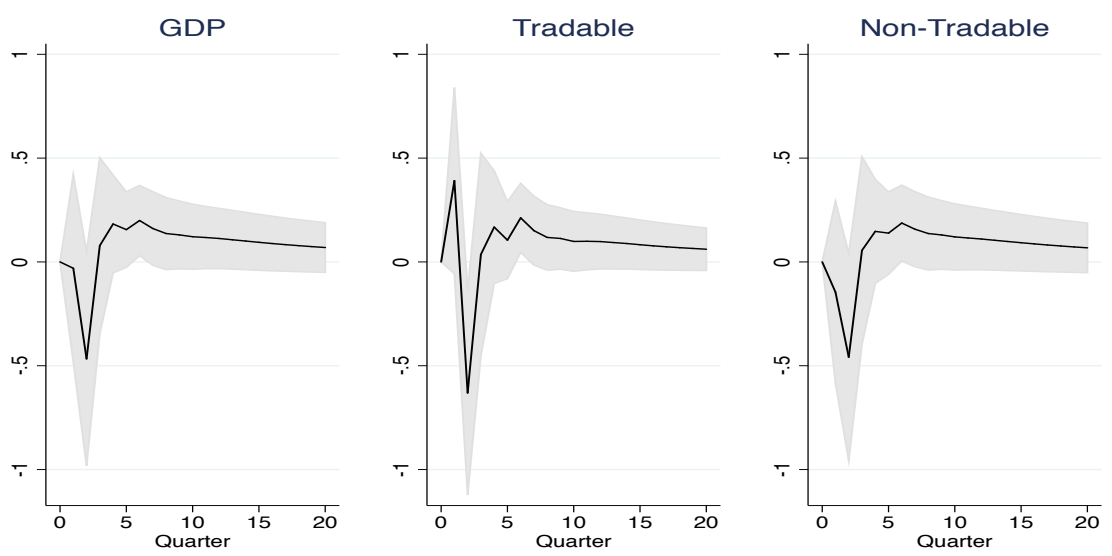

Output Responses to a US Interest Rate Shock
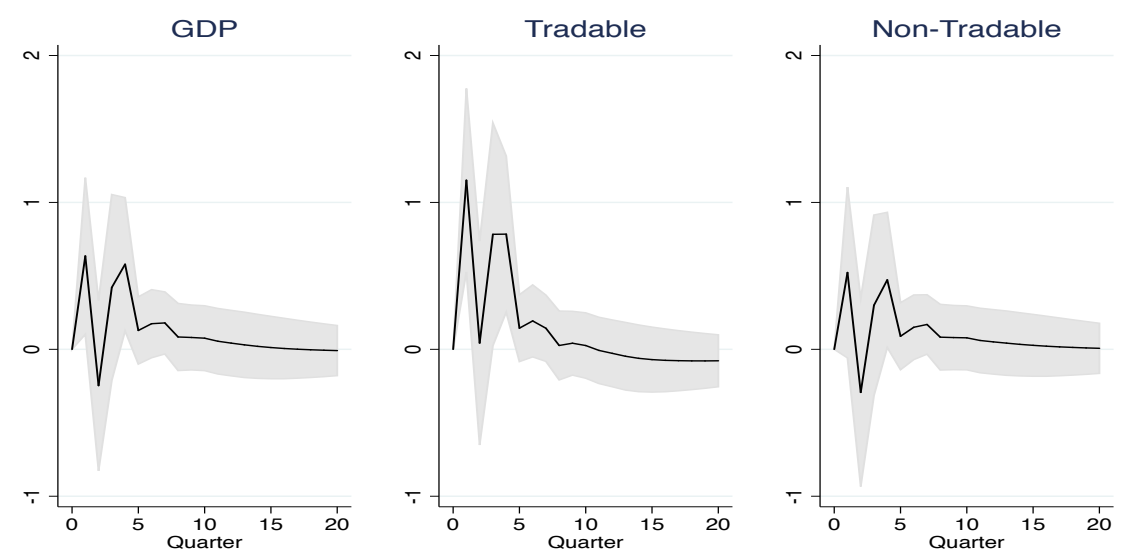

Figure 2: Developed Open Economies: IRFs to Interest Rate Shocks

\subsubsection{Variance Decomposition}

To understand the contribution of interest rate shocks on GDP and the output of each sector, I perform a variance decomposition analysis. In particular, the orthogonalization of the VAR residuals discussed above allows to account for the change in output growth stemming from each of the shocks. The empirical results presented in Table 3 point that, in emerging markets, country interest rate shocks account for about 14\% of GDP fluctuations within a business cycle frequency (column 1). Remarkably, GDP fluctuations are mainly explained by changes in non-tradable activities. As shown in columns 2 and 3, domestic interest rate shocks account for $11 \%$ of the output variation in the non-tradable sector, and about $7 \%$ of its variation in the tradable sector in emerging markets. Interestingly, U.S. interest rate shocks only explain a small proportion of the disturbances in aggregate 
fluctuations in these economies. Notice that, unlike emerging markets, domestic interest rate shocks explain a minor part of output fluctuations in both tradable and non-tradable activities in developed open economies.

Table 3: Variance Decomposition to Interest Rate Shocks

\begin{tabular}{|c|c|c|c|c|c|c|}
\hline \multirow[b]{3}{*}{ Quarter } & \multicolumn{3}{|c|}{ Emerging Markets } & \multicolumn{3}{|c|}{ Developed Open Economies } \\
\hline & GDP & Tradable & $\begin{array}{l}\text { Non- } \\
\text { Tradable }\end{array}$ & GDP & Tradable & $\begin{array}{l}\text { Non- } \\
\text { Tradable }\end{array}$ \\
\hline & $(1)$ & $(2)$ & $(3)$ & $(4)$ & $(5)$ & $(6)$ \\
\hline \multicolumn{7}{|c|}{ Domestic Interest Rate } \\
\hline 1 & 13.2 & 6.3 & 10.7 & 1.6 & 1.6 & 1.5 \\
\hline 2 & 13.4 & 6.4 & 10.9 & 1.5 & 2.0 & 1.4 \\
\hline 3 & 13.5 & 6.5 & 10.9 & 1.8 & 2.4 & 1.7 \\
\hline 4 & 13.5 & 6.5 & 10.9 & 1.8 & 2.4 & 1.7 \\
\hline 8 & 13.6 & 6.6 & 11.0 & 1.9 & 2.4 & 1.8 \\
\hline 20 & 13.7 & 6.8 & 11.1 & 2.1 & 2.5 & 1.9 \\
\hline \multicolumn{7}{|c|}{ U.S. Interest Rate } \\
\hline 1 & 0.1 & 0.2 & 0.1 & 0.3 & 0.2 & 0.4 \\
\hline 2 & 0.1 & 0.2 & 0.1 & 0.4 & 0.7 & 0.4 \\
\hline 3 & 0.1 & 0.2 & 0.1 & 0.4 & 0.7 & 0.4 \\
\hline 4 & 0.1 & 0.2 & 0.1 & 0.5 & 1.0 & 0.5 \\
\hline 8 & 0.1 & 0.2 & 0.1 & 0.8 & 1.4 & 0.7 \\
\hline 20 & 0.1 & 0.2 & 0.1 & 0.8 & 1.4 & 0.7 \\
\hline
\end{tabular}

The results presented in this section suggest that it is the presence of financial frictions in emerging markets what amplifies the initial shock by raising the risk premium perceived by non-tradable activities and propagating the shock to these activities. This amplification mechanism seems to be at the center of the economic downturn of aggregate activities following increases in the borrowing cost.

\subsubsection{Sensitivity Analysis}

To assess the robustness of the results, I conduct two further empirical exercises. I first analyze the sensitivity of the results for different classifications of non-tradable activities, and test next whether results are robust to different specifications of VAR.

\section{-Non-Tradable Activities}

Results presented above considered a broad definition of non-tradable activities that included all economic activities except for agriculture, fishing, mining and manufacturing. 
More precisely, the non-tradable sector included: utilities, construction, trade, transportation and accommodation, information and communication, financial and real estate activities, professional activities, public administration, education, health, arts and other private services. ${ }^{6}$ In this section, I consider two robustness tests. I first exclude financial and real estate activities from the analysis, and next I also exclude government regulated activities, as utilities (electricity, gas and water supply), public administration, eduction and health services, as these activities are subject to specific regulations.

Figures A1 and A2 in Appendix A present the impulse response functions of the two classifiations of non-tradable activities to domestic and foreign interest rate shocks for emerging markets and developed open economies. As shown by Figure A1, the response of non-tradable output to domestic interest rate shocks remains negative and statistically significant when excluding financial and real estate activities from the analysis. The response is similar in magnitude than previously estimated: one percentage point increase in the domestic interest rate correlates with a drop of $7 \%$ in non-tradable output within a quarter. Similarly, non-tradable activities respond negatively and statistically significant to domestic interest rate shocks when government regulated activities are as well excluded from the analysis. The estimated coefficient implies that an innovation in the domestic interest rate decreases non-tradable output by $4 \%$ within a quarter, and $5 \%$ in the second quarter. ${ }^{7}$ As above, Figure A1 show that the non-tradable output responses to innovations in the U.S. interest rate are statistically non-significant. Notice that innovations to the domestic and U.S. interest rate are non-statistically significant in developed open economies, as shown in Figure A2.

Table A1 reports the variance decomposition analysis of domestic and foreign interest rate shocks. Column 1 shows that, in emerging markets, innovations in the domestic interest rate explain about $9 \%$ of movements in non-tradable output at business cycle frequency (20 quarters) when the financial sector is excluded from the sample. When government regulated activities and the financial sector are both excluded from analysis in column 2 , innovations in the domestic interest rate explain about $12 \%$ of the fluctuations in non-tradable activities. Similar to Table 3, innovations in the U.S. interest rate only explain a small proportion of fluctuations in non-tradable activities in emerging markets. Note, finally, that innovation to the domestic and U.S. interest rate explain a minor proportion of non-tradable output fluctuations in developed open economies independently of the classification of these activities.

\footnotetext{
${ }^{6}$ See Calvo, Izquierdo, and Mejía (2004) for a similar decomposition of sectors.

${ }^{7}$ It is worth noting that the sample size drops to eighteen emerging markets, as some countries do not report government regulated activities separately. The countries included in the sample are: Argentina, Bulgaria, Chile, Czech Republic, Hungary, Indonesia, Iran, Korea, Malaysia, Mexico, Nigeria, Peru, Philippines, South Africa, Taiwan, Thailand, Tunisia, Turkey and Ukraine.
} 


\section{-Structural VAR and Generalized Impulse Restrictions}

The results presented in Section 3.2 are estimated following a Cholesky decomposition, where the identification assumption is that innovations in the interest rate affect sectoral output contemporaneously and with a lag, while sectoral outputs only impact the interest rate with a lag. In this section, I perform two sensitivity analysis. First, I perform a generalized impulse analysis, which does not require the orthogonalization of the shocks and is invariant to the ordering of the variables in the VAR system. ${ }^{8}$ Second, I estimate a long-term structural VAR, where the identifying assumption is that shocks to the shortterm interest rate have no long-term effect on output growth. ${ }^{9}$

Figures B.1 and B.2 in Appendix B present the generalized impulse responses of GDP and sectoral output to domestic and foreign interest rate shocks for emerging markets at business cycle frequency. Dash lines represent 5\% error banks generated by Monte Carlo simulations with 1,000 repetitions. As in Section 3.2, GDP and non-tradable output responses to domestic interest rate shocks are negative and statistically significant (Figure B.1). Just like the previous trend in the tradable sector, the response to innovations in the country interest rate is statistically non-significant. Figure B.2 presents the generalized impulse responses to innovations in the U.S. interest rate in emerging markets, and indicates that neither GDP or sectoral outputs respond significanty to these shocks.

Figures B.3 and B.4 plot the impulse response functions to innovation in the domestic and foreign interest rate estimated with the long-term structural VAR for emerging market. As above, GDP and non-tradable output respond negatively to domestic interest rate shocks, while the tradable sector remains unaffected (Figure B.3). The responses to innovations in the U.S interest rate are statistically non-significant (Figure B.4).

For robustness, Figures B.5- B.8 plot the generalized impulse responses and IRF of the long-term structural VAR for developed open economies. Finally, Figures B.9-B.12 plot the GDP and non-tradable output responses to domestic interest rate shocks for the twenty emerging market estimated individually. These figures illustrate that the negative responses of GDP and non-tradable activities to domestic interest rate shocks remain true across countries and, as such, this negative relationship is a wide-spread phenomenon in emerging markets.

\footnotetext{
${ }^{8}$ See Pesaran and Shin (1998) for a discussion on for generalized impulse analysis

${ }^{9}$ The identification assumption follows the seminal paper of Blanchard and Quah (1989). In particular, I consider that there are two disturbances affecting output growth and the interest rate. The first has no long-term effect on either output growth or the interest rate. The second has no long run effect on the interest rate, but it might affect output growth.
} 


\subsection{Domestic Credit and Sectoral Output Growth}

Section 3.2 has shown that in emerging markets tradable and non-tradable activities respond asymmetrically to changes in the domestic interest rate. Interesting, this distinctive response across sectors is absent in open economies with developed capital markets. Why do we observe this asymmetric response between tradable and non-tradable activities in emerging markets? Previous studies suggest that this heterogeneity could stem from differences in financial opportunities between tradable and non-tradable firms in these economies. In particular, Tornell and Westermann (2005) document that tradable firms see easier access to international capital markets as -for instance- they can pledge their exports as collateral, while non-tradable firms are typically smaller and face greater obstacles to obtain international credit. This higher reliance on less developed capital markets could account for the larger downturns observed in non-tradable activities in emerging markets. To assess this, I now turn to study domestic credit and output relationships at sector level in emerging markets.

With this end, I estimate a heterogenous dynamic panel using a mean group estimators. I let the the dependent variable be sectoral output growth and the explanatory variable be sectoral credit growth, and control for trade openness (export plus imports over GDP), real exchange rate, country-fixed effects and currency and banking crisis (see Section 3.1 describing the data). Finally, I present two sensitivity analysis for different classification of non-tradable activities and specification of the dynamic heterogenous panel.

\subsubsection{Mean Group Estimator}

To study how sectoral credit and output relate, I compute a mean group estimator that separately estimates the short- and long-term relationships for each country, and averages the results across them. ${ }^{10}$ The advantage of the mean group estimator to study emerging markets is that it estimates the dynamic of each country individually. Given the heterogenous pattern of growth of emerging markets, jointly estimate their dynamic could induce to measurement error problems and bias the estimators. The empirical model has the following form,

$$
\Delta y_{(i, t)}=\sum_{j=1}^{p-1} \gamma_{j} \Delta y_{(i, t-1)}+\sum_{j=0}^{q-1} \rho_{j} \Delta x_{(i, t-q)}+\phi\left[y_{(i, t-1)}-\left\{\beta_{(0, j)}+\beta_{(1, j)} x_{(i, t-1)}\right\}\right]+\epsilon_{t}
$$

\footnotetext{
${ }^{10}$ See Pesaran, Shin, and Smith (2004) for a detailed discussion about dynamic heterogenous panels.
} 
The first term on the right hand side of equation (4) accounts for the effect of past output growth on current production $(y)$. The second term is the term under study and indicates how changes in domestic credit affect short-term production in each sector $(x)$. The term in brackets reports the long-term relationship between sectoral credit and output. The order of lags is determined by the AIC and BIC criteria, and indicate one lag for both variables. I estimate these relationships for GDP, tradable and non-tradable activities separately. Next, to test whether the dynamic between tradable and non-tradable sectors differs, I use the data jointly and interact sectoral credit with a binary variable indicating the sector. With this purpose, I re-estimate the model as follows,

$$
\begin{gathered}
\Delta y_{(i, t)}=\sum_{j=1}^{p-1} \gamma_{j} \Delta y_{(i, t-1)}+\sum_{j=0}^{q-1} \rho_{(0, j)} \Delta x_{(i, t-q)}+\sum_{j=0}^{q-1} \rho_{(1, j)} N T * \Delta x_{(i, t-q)}+ \\
\phi\left[y_{(i, t-1)}-\left\{\beta_{(0, j)}+\beta_{(1, j)} x_{(i, t-1)}+\beta_{(2, j)} N T * x_{(i, t-1)}\right\}\right]+\epsilon_{t}
\end{gathered}
$$

where $N T$ represents a binary variable for the non-tradable sector.

Table 4 reports the main results of the dynamic heterogenous panel. Columns 1 and 2 document a strong short-term correlation between domestic credit and GDP growth. In particular, column 1 indicates that one percent increase in the growth rate of domestic credit is associated with an expansion of more than one third in GDP growth, after controlling for changes in trade openness and the exchange rate. The inclusion of the control for currency and banking crisis in column 2 does not affect the magnitude of the estimated coefficient, which remains at a level of $34 \%$ and statistically significant at one percent. This tight relationship between domestic credit and GDP growth suggests that domestic economic activities are still highly dependent on local credit market in emerging markets.

Columns 3-6 report credit and output relationship for the tradable and non-tradable sectors estimated individually. Remarkably, the coefficient estimating the relationship between tradable credit and output is small and non-statistically significant, which suggests that output growth in the tradable sector does not rely on the domestic credit allocated to that sector (columns 3 and 4). Unlike the tradable sector, non-tradable activities rely intensively on domestic credit. After the inclusion of all controls, the estimated coefficient implies that one percent increase in the credit allocated to this sector increases non-tradable output growth by $34 \%$ (column 6 ). Columns 7 and 8 confirm this hypothesis by estimating the differential impact of non-tradable credit on output growth. The interaction term of equation (5) in column 8 implies that an expansion of sectoral credit raises output growth by $4.2 \%$ more in non-tradable than in tradable activities. 
Table 4: Emerging Markets: Sectoral Output and Credit Relationship-MG

\begin{tabular}{|c|c|c|c|c|c|c|c|c|}
\hline & \multicolumn{8}{|c|}{ Mean Group } \\
\hline & \multicolumn{2}{|c|}{ GDP } & \multicolumn{2}{|c|}{ Tradable } & \multicolumn{2}{|c|}{ Non-Tradable } & \multicolumn{2}{|c|}{ Interaction } \\
\hline & (1) & $(2)$ & (3) & $(4)$ & (5) & $(6)$ & $(7)$ & $(8)$ \\
\hline \multicolumn{9}{|l|}{ Short-Term Coeff. } \\
\hline$\Delta$ Credit & $\begin{array}{l}0.362^{* * *} \\
(0.075)\end{array}$ & $\begin{array}{l}0.344^{* * *} \\
(0.069)\end{array}$ & $\begin{array}{l}0.135 \\
(0.090)\end{array}$ & $\begin{array}{l}0.117 \\
(0.086)\end{array}$ & $\begin{array}{l}0.430^{* *} \\
(0.190)\end{array}$ & $\begin{array}{l}0.344^{* * *} \\
(0.066)\end{array}$ & $\begin{array}{l}0.100^{* * *} \\
(0.032)\end{array}$ & $\begin{array}{l}0.085^{* * *} \\
(0.028)\end{array}$ \\
\hline$\Delta \mathrm{NT}^{*}$ Credit & & & & & & & $\begin{array}{l}0.047^{* *} \\
(0.024)\end{array}$ & $\begin{array}{l}0.042^{*} \\
(0.022)\end{array}$ \\
\hline$\Delta$ Credit $(-1)$ & $\begin{array}{l}0.081 \\
(0.052)\end{array}$ & $\begin{array}{l}0.093^{*} \\
(0.054)\end{array}$ & $\begin{array}{l}-0.048 \\
(0.051)\end{array}$ & $\begin{array}{l}-0.047 \\
(0.052)\end{array}$ & $\begin{array}{l}0.158^{*} \\
(0.095)\end{array}$ & $\begin{array}{l}0.060 \\
(0.060)\end{array}$ & $\begin{array}{l}-0.020 \\
(0.029)\end{array}$ & $\begin{array}{l}-0.026 \\
(0.027)\end{array}$ \\
\hline$\Delta \mathrm{NT}^{*}$ Credit $(-1)$ & & & & & & & $\begin{array}{l}0.008 \\
(0.012)\end{array}$ & $\begin{array}{l}0.009 \\
(0.013)\end{array}$ \\
\hline$\Delta$ Output $(-1)$ & $\begin{array}{l}0.071 \\
(0.050)\end{array}$ & $\begin{array}{l}0.027 \\
(0.056)\end{array}$ & $\begin{array}{l}0.074 \\
(0.057)\end{array}$ & $\begin{array}{l}0.042 \\
(0.057)\end{array}$ & $\begin{array}{l}0.062 \\
(0.053)\end{array}$ & $\begin{array}{l}-0.004 \\
(0.071)\end{array}$ & $\begin{array}{l}0.068^{*} \\
(0.040)\end{array}$ & $\begin{array}{l}0.031 \\
(0.041)\end{array}$ \\
\hline$\Delta$ Trade Openness & $\begin{array}{l}-0.260^{* * *} \\
(0.048)\end{array}$ & $\begin{array}{l}-0.261^{* * *} \\
(0.048)\end{array}$ & $\begin{array}{l}-0.217^{* * *} \\
(0.058)\end{array}$ & $\begin{array}{l}-0.225^{* * *} \\
(0.057)\end{array}$ & $\begin{array}{l}-0.300^{* * *} \\
(0.064)\end{array}$ & $\begin{array}{l}-0.272^{* * *} \\
(0.055)\end{array}$ & $\begin{array}{l}-0.223^{* * *} \\
(0.037)\end{array}$ & $\begin{array}{l}-0.230^{\text {*** }} \\
(0.037)\end{array}$ \\
\hline$\Delta$ Exchange Rate & $\begin{array}{l}0.289^{* * *} \\
(0.107)\end{array}$ & $\begin{array}{l}0.206 \\
(0.137)\end{array}$ & $\begin{array}{l}0.476^{* * *} \\
(0.179)\end{array}$ & $\begin{array}{l}0.384^{* *} \\
(0.185)\end{array}$ & $\begin{array}{l}0.450 \\
(0.275)\end{array}$ & $\begin{array}{l}0.218 \\
(0.172)\end{array}$ & $\begin{array}{l}0.255^{* *} \\
(0.123)\end{array}$ & $\begin{array}{l}0.160 \\
(0.139)\end{array}$ \\
\hline Crisis & & $\begin{array}{l}-0.027^{* *} \\
(0.011)\end{array}$ & & $\begin{array}{l}-0.030^{* * *} \\
(0.010)\end{array}$ & & $\begin{array}{l}-0.016 \\
(0.011)\end{array}$ & & $\begin{array}{l}-0.028^{* * *} \\
(0.007)\end{array}$ \\
\hline \multicolumn{9}{|l|}{ Long-Term Coeff. } \\
\hline ECC & $\begin{array}{l}-0.107 \\
(0.077)\end{array}$ & $\begin{array}{l}-0.102 \\
(0.077)\end{array}$ & $\begin{array}{l}-0.319^{* * *} \\
(0.091)\end{array}$ & $\begin{array}{l}-0.308^{* * *} \\
(0.089)\end{array}$ & $\begin{array}{l}-0.003 \\
(0.190)\end{array}$ & $\begin{array}{l}-0.028 \\
(0.018)\end{array}$ & $\begin{array}{l}-0.267^{* * * *} \\
(0.055)\end{array}$ & $\begin{array}{l}-0.252^{\text {*** }} \\
(0.054)\end{array}$ \\
\hline Credit & $\begin{array}{l}0.510^{* * *} \\
(0.156)\end{array}$ & $\begin{array}{l}0.234 \\
(0.185)\end{array}$ & $\begin{array}{l}0.019 \\
(0.355)\end{array}$ & $\begin{array}{l}0.037 \\
(0.327)\end{array}$ & $\begin{array}{l}-0.544 \\
(0.916)\end{array}$ & $\begin{array}{l}0.985^{* * *} \\
(0.180)\end{array}$ & $\begin{array}{c}-0.027 \\
(0.169)\end{array}$ & $\begin{array}{l}-0.017 \\
(0.158)\end{array}$ \\
\hline NT*Credit & & & & & & & $\begin{array}{l}-0.129 \\
(0.227)\end{array}$ & $\begin{array}{l}-0.091 \\
(0.199)\end{array}$ \\
\hline Trade Openness & $\begin{array}{l}-0.537^{* *} \\
(0.262)\end{array}$ & $\begin{array}{l}-0.070 \\
(0.552)\end{array}$ & $\begin{array}{l}-0.763^{* *} \\
(0.303)\end{array}$ & $\begin{array}{l}-0.803^{* * *} \\
(0.295)\end{array}$ & $\begin{array}{l}-1.594 \\
(0.990)\end{array}$ & $\begin{array}{l}-1.509^{* *} \\
(0.723)\end{array}$ & $\begin{array}{l}-1.232^{* *} \\
(0.515)\end{array}$ & $\begin{array}{l}-1.338^{* * *} \\
(0.468)\end{array}$ \\
\hline Exchange Rate & $\begin{array}{l}0.340 \\
(1.625)\end{array}$ & $\begin{array}{l}2.302 \\
(1.678)\end{array}$ & $\begin{array}{l}1.383 \\
(1.603)\end{array}$ & $\begin{array}{l}1.424 \\
(1.582)\end{array}$ & $\begin{array}{l}1.588 \\
(1.233)\end{array}$ & $\begin{array}{l}-1.313^{*} \\
(0.764)\end{array}$ & $\begin{array}{l}1.599^{*} \\
(0.941)\end{array}$ & $\begin{array}{l}1.904^{* *} \\
(0.967)\end{array}$ \\
\hline $\mathrm{N}$ & 757 & 757 & 757 & 757 & 757 & 757 & 1,514 & 1,514 \\
\hline
\end{tabular}

\subsubsection{Sensitivity Analysis}

In this section, I undertake two robustness tests. I test whether results are robust to different classification of non-tradable activities, and to a distinct specification of the dynamic heterogenous panel.

\section{-Non-Tradable Activities}

Results in Table 4 considered a broad definition of non-tradable activities, where all economic activities except for agriculture, fishing, mining and manufacture were included in the non-tradable sector. I turn now to conduct two sensitivity analysis for non-tradable activities. As in Section 3.2.4, I consider two alternative definitions for non-tradable activities. I first exclude financial and real estate activities from the analysis, and next all 
government regulated activities.

Results are presented in Table A2. Column 1 shows that non-tradable output remains reliant of domestic credit when the financial and retail activities are excluded from the sample. In particular, one percent increase in non-tradable credit is associated in an expansion of about $20 \%$ in non-tradable output. The further dependence of non-tradable activities to local credit holds true when estimating both sectors jointly. As shown in column 2, an expansion of sectoral credit raises output growth by $4.2 \%$ more in the non-tradable sector. Columns 3 and 4 report the results for the sample of non-tradable activities when financial and real estate activities and government regulated activities are excluded from the analysis. The estimated coefficient on the short-term non-tradable credit on output growth -reported in column 3- indicates that one percent increase in domestic credit leads to non-tradable output growth by $22 \%$ within a quarter. The interaction term (in column 4 ) is statistically significant and implies that an expansion of sectoral credit differentially increase output growth by about $5 \%$ in the non-tradable sector.

\section{-Pooled-Mean Group}

For comparison, I also compute a pooled-mean group of equation (4). The pooled-mean group estimates heterogenous short-term dynamics across countries, and a common longterm relationship to all countries. More precisely, it proceeds first to calculate the longterm coefficients jointly for all countries using a maximum likelihood procedure, where the long-term homogenous dynamics is given by $\beta_{(0, j)}=\beta_{(0)}, \beta_{(1, j)}=\beta_{(1)}$, and $\beta_{(2, j)}=\beta_{(2)}$ in equations (4) and (5). It turn next to estimate the short-term coefficients, the countryspecific intercept, and the country-specific error variances for each country, also through a maximum likelihood procedure and using the estimates of the long-term relationships computed in the first step.

Table B.5 in Appendix B presents the estimated results, and confirms the greater reliance of non-tradable output to domestic credit in emerging markets. After the inclusion of controls, the estimated coefficient in column 2 implies that one percent increase in credit growth associates with a $42 \%$ expansion in GDP growth within a quarter. Columns 3-6 present the results for tradable and non-tradable sector separately. The coefficients on non-tradable activities are substantially larger in magnitude than those of tradable activities. Furthermore, the coefficient of the interaction term in column 8 -once all controls are included- implies that an increase in domestic credit is associated with a differential expansion of non-tradable output growth of $8 \%$, above the expansion of the tradable sector.

Results presented in this section show that non-tradable activities are more reliant on local credit and, hence, more likely to be affected by changes in domestic financial 
terms. This stronger dependence on the local financial system and the greater downturn of non-tradable activities following interest rate shocks argue in favor of an amplification mechanism, working through local financial imperfections and mainly affecting activities relying on the local financial system, i.e. non-tradable activities.

\section{Conclusion}

Interest rate shocks have a large impact on aggregate activities in emerging markets. This paper has shown that this economic downturn stems from the fall in non-tradable activities. Importantly, the asymmetric response between tradable and non-tradable activities is characteristic of emerging markets and absent in open economies with developed capital markets. Why do we observe this asymmetric sectoral response in emerging markets? This paper argues that it is the heterogeneous access to external finance which can account for this fact. In particular, as shown above, non-tradable activities are more reliant on the local credit market and, thus, more exposed to the local financial frictions predominant in these economies. It is the presence of local financial imperfections that amplifies the initial increase in the borrowing cost and affects those activities depending more intensively on local credits.

This paper contributes to the literature showing that the high volatility of emerging markets is related to the prevalence of financial frictions in these economies. Given the increasing importance of emerging markets for the global economy as well as the limited scope for their residents to share domestic income risk, the question of how to enhance the economic stability in these countries is of significant interest to policy makers within as well as outside the countries in question. By highlighting that the vulnerability of emerging markets to country interest rate shocks derives chiefly from the vulnerability of their non-tradable sectors to such shocks, this paper implies that stability-enhancing policy reforms should aim to increase the access to credit of firms in this sector. Traditionally, development policy has focused on credit access for tradable firms, to aid the growth of a country's exporting sector. Based on my findings, countries with a well developed export sector should also improve credit access to domestically operating firms, so as to stabilize their economies in the face of external shocks. 


\section{References}

Alfaro, L., A. Chari, And F. Kanczuk (2016): "The Real Effects of Capital Controls: Financial Constraints, Exporters, and Firm Investment," Working Papers 15-016, Harvard Business School.

Arellano, C., Y. Bai, AND J. Zhang (2012): "Firm dynamics and financial development," Journal of Monetary Economics, 59(6), 533-549.

Blanchard, O. J., And D. Quah (1989): "The Dynamic Effects of Aggregate Demand and Supply Disturbances," American Economic Review, 79(4), 655-73.

Blankenau, W., A. Kose, And K.-M. Yi (2001): "Can world real interest rates explain business cycles in a small open economy?," Journal of Economic Dynamics and Control, 25(6-7), 867-889.

BRodA, C. (2004): "Terms of trade and exchange rate regimes in developing countries," Journal of International Economics, 63(1), 31-58.

Calvo, G. A., A. Izquierdo, And L. F. Mejía (2004): "On the Empirics of Sudden Stops: The Relevance of Balance-Sheet Effects," Research Department Publications 4367, Inter-American Development Bank, Research Department.

Calvo, G. A., L. Leiderman, And C. M. Reinhart (1993): "Capital Inflows and Real Exchange Rate Appreciation in Latin America: The Role of External Factors," IMF Staff Papers, 40(1), 108-151.

Canova, F. (2005): "The Transmission of US Shocks to Latin America," Journal of Applied Econometrics, $20(2), 229-251$.

Chang, R., And A. Fernandez (2013): "On the Sources of Aggregate Fluctuations in Emerging Markets," International Economic Review, 54(4), 1265-1293.

Eaton, J., And M. Gersovitz (1981): "Debt with Potential Repudiation: Theoretical and Empirical Analysis," Review of Economic Studies, 48(2), 289-309.

Holtz-Eakin, W. N., And H. S. Rosen (1988): "Estimating Vector Autoregressions with Panel Data," Econometrica, 56 (6), 1371-1395.

Kaminsky, G. L. (2006): "Variety of Currency Crises," Journal of International Money and Finance.

Kletzer, K., AND P. BARdhan (1987): "Credit markets and patterns of international trade," Journal of Development Economics, 27(1-2), 57-70.

Kose, M. A. (2002): "Explaining business cycles in small open economies: 'How much do world prices matter?'," Journal of International Economics, 56(2), 299-327.

Love, I., AND L. Zicchino (2006): "Financial development and dynamic investment behavior: Evidence from panel VAR," The Quarterly Review of Economics and Finance, 46(2), 190-210.

MendozA, E. G. (1995): "The Terms of Trade, the Real Exchange Rate, and Economic Fluctuations," International Economic Review, 36(1), 101-37.

Neumeyer, P. A., AND F. Perri (2005): "Business cycles in emerging economies: the role of interest rates," Journal of Monetary Economics, 52(2), 345-380. 
Pesaran, H. H., AND Y. Shin (1998): "Generalized impulse response analysis in linear multivariate models," Economics Letters, 58(1), 17-29.

Pesaran, M., Y. Shin, And R. P. Smith (2004): "Pooled mean group estimation of dynamic heterogeneous panels," Journal of the American Statistical Association, (94(446)).

Reinhart, C. M., AND K. S. Rogoff (2010): This Time Is Different: Eight Centuries of Financial Folly. Princeton University Press.

Tornell, A., AND F. Westermann (2005): Boom-Bust Cycles and Financial Liberalization. CESifo Book Series, MIT Press.

URibe, M., AND V. Z. Yue (2006): "Country spreads and emerging countries: Who drives whom?," Journal of International Economics, 69(1), 6-36.

WorldBank (2004): Global Development Finance. 


\section{Appendix A Additional Figures and Tables}

Output Responses to a Domestic Interest Rate Shock
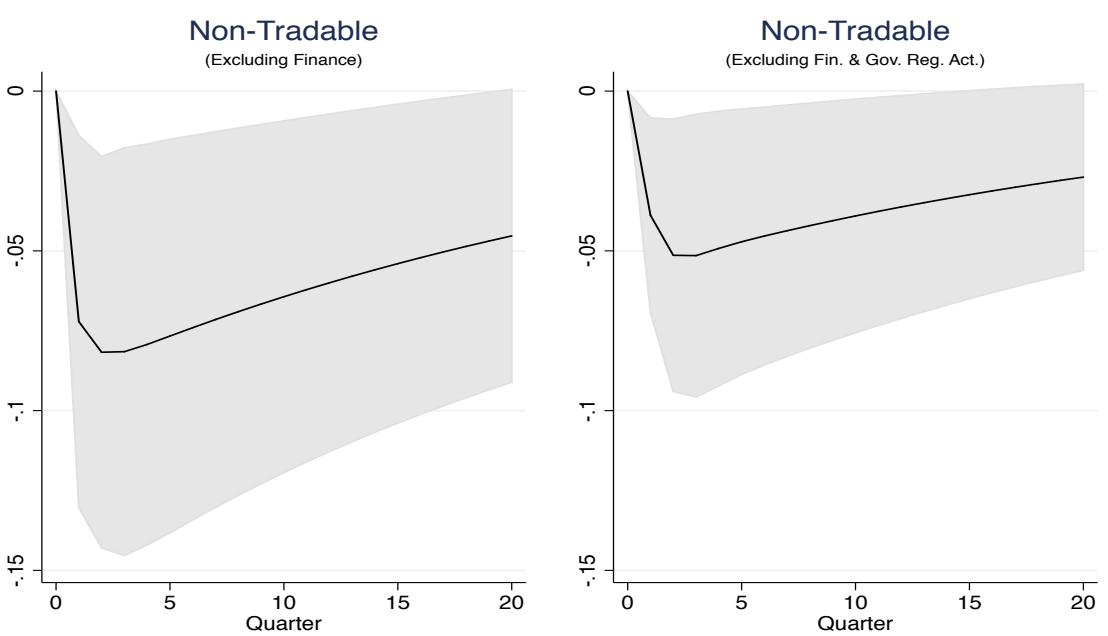

Output Responses to a US Interest Rate Shock
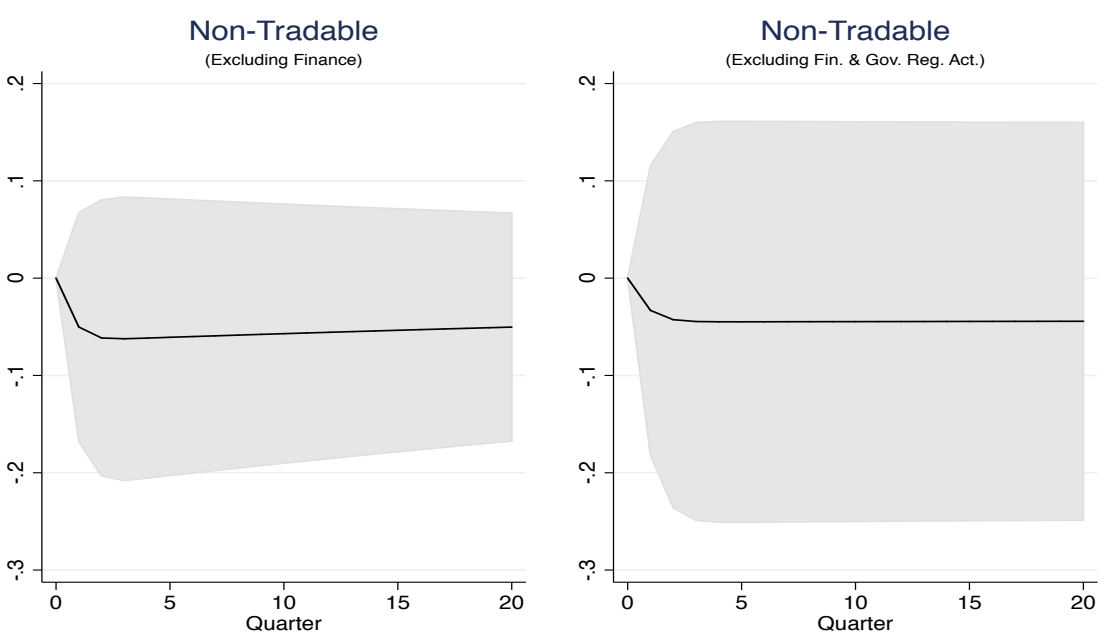

Figure A1: Emerging Markets: IRFs to Interest Rate Shocks- Robustness 


\section{Output Responses to a Domestic Interest Rate Shock}
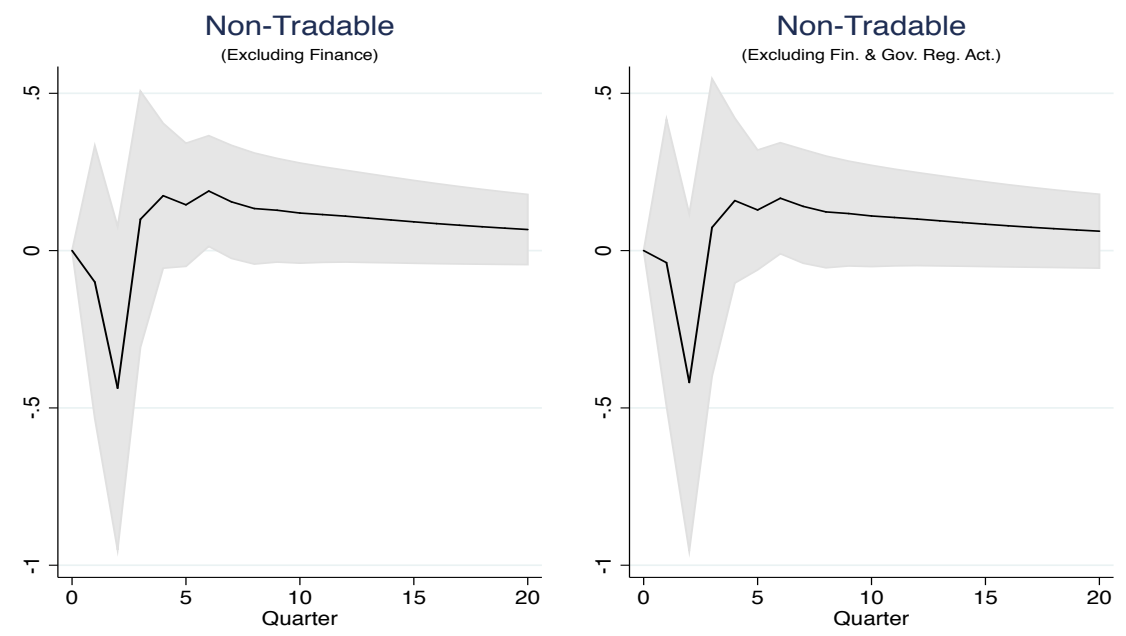

Output Responses to a US Interest Rate Shock
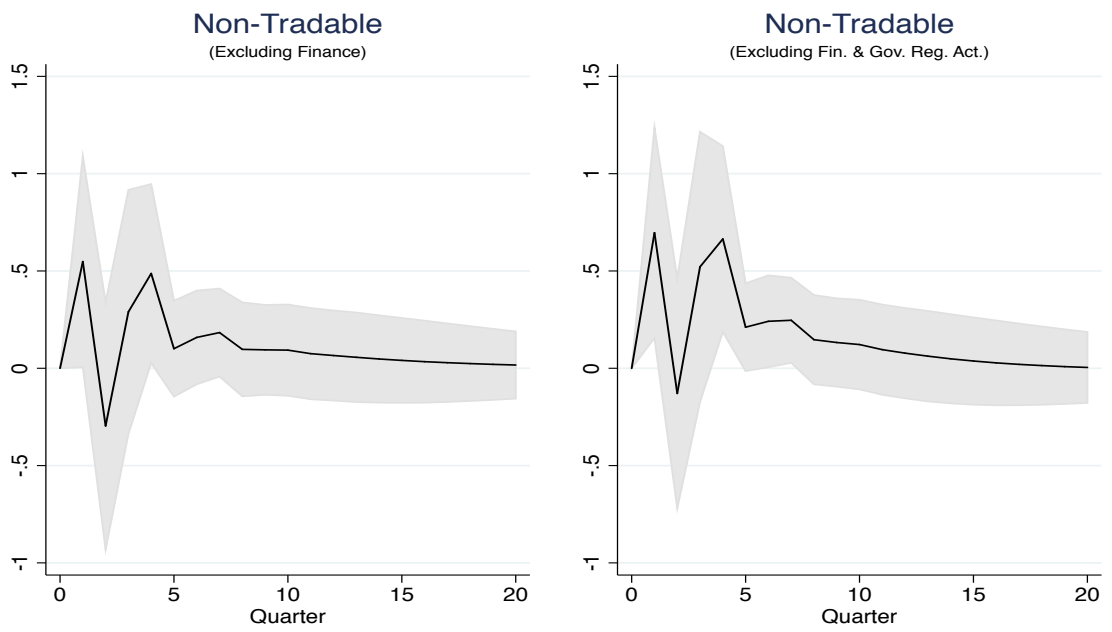

Figure A2: Developed Open Economies: IRFs to Interest Rate Shocks- Robustness 
Table A1: Variance Decomposition to Interest Rate Shocks- Robustness for NT Activities

\begin{tabular}{|c|c|c|c|c|}
\hline \multirow[b]{4}{*}{ Quarter } & \multicolumn{2}{|c|}{ Emerging Markets } & \multicolumn{2}{|c|}{ Developed Open Economies } \\
\hline & \multirow{3}{*}{$\begin{array}{l}\text { Non-Tradable } \\
\text { Excluding Finance } \\
\text { (1) }\end{array}$} & \multirow{3}{*}{$\begin{array}{l}\text { Non-Tradable } \\
\text { Excl. Fin. \& Gov. } \\
\text { Reg. Act. } \\
(2)\end{array}$} & \multirow{3}{*}{$\begin{array}{l}\text { Non-Tradable } \\
\text { Excluding Finance } \\
(3)\end{array}$} & \multirow{3}{*}{$\begin{array}{l}\text { Non-Tradable } \\
\text { Excl. Fin. \& Gov. } \\
\text { Reg. Act. } \\
\text { (4) }\end{array}$} \\
\hline & & & & \\
\hline & & & & \\
\hline \multicolumn{5}{|c|}{ Domestic Interest Rate } \\
\hline 1 & 8.4 & 11.4 & 1.4 & 1.7 \\
\hline 2 & 8.5 & 11.5 & 1.3 & 1.7 \\
\hline 3 & 8.5 & 11.6 & 1.6 & 1.9 \\
\hline 4 & 8.6 & 11.6 & 1.6 & 1.9 \\
\hline 8 & 8.6 & 11.6 & 1.7 & 1.9 \\
\hline 20 & 8.8 & 11.7 & 1.8 & 2.1 \\
\hline \multicolumn{5}{|c|}{ U.S. Interest Rate } \\
\hline 1 & 0.1 & 0.1 & 0.4 & 0.3 \\
\hline 2 & 0.1 & 0.1 & 0.4 & 0.4 \\
\hline 3 & 0.1 & 0.1 & 0.5 & 0.4 \\
\hline 4 & 0.1 & 0.1 & 0.5 & 0.6 \\
\hline 8 & 0.1 & 0.1 & 0.8 & 1.0 \\
\hline 20 & 0.1 & 0.1 & 0.8 & 1.0 \\
\hline
\end{tabular}

Notes: In percentage. Period: 1990q1: 2015q4. The real interest rate for developed small open economies is the short-term 3-month interest rate from MEI-OECD; the real interest rate for emerging markets is computed as the U.S. Tbill + EMBI GLOBAL. DOEs: Australia, Austria, Belgium, Canada, Denmark, Finland, France, Ireland, Italy, Netherlands, Norway, Portugal, Spain, Sweden, and Switzerland. EMs: Argentina, Bulgaria, Chile, Czech Republic, Hungary, Indonesia, Iran, Korea, Malaysia, Mexico, Nigeria, Peru, South Africa, Taiwan, Thailand, Tunisia, Turkey and Ukraine. 
Table A2: EMs: Sectoral Output and Credit Relationship-MG, Robustness

\begin{tabular}{|c|c|c|c|c|}
\hline & \multicolumn{2}{|c|}{ Excluding Finance } & \multicolumn{2}{|c|}{ Excluding Gov. Regulated Activities } \\
\hline & Non-Tradable & Interaction & Non-Tradable & Interaction \\
\hline & (1) & $(2)$ & (3) & (4) \\
\hline $\begin{array}{l}\text { Short-Term Coeff. } \\
\Delta \text { Credit }\end{array}$ & $\begin{array}{l}0.197^{* * *} \\
(0.053)\end{array}$ & $\begin{array}{l}0.095^{* * *} \\
(0.031)\end{array}$ & $\begin{array}{l}0.219^{* * *} \\
(0.048)\end{array}$ & $\begin{array}{l}0.095^{* * *} \\
(0.031)\end{array}$ \\
\hline$\Delta \mathrm{NT}^{*}$ Credit & & $\begin{array}{l}0.042^{* * *} \\
(0.015)\end{array}$ & & $\begin{array}{l}0.048^{* * *} \\
(0.015)\end{array}$ \\
\hline$\Delta$ Credit $(-1)$ & $\begin{array}{l}0.033 \\
(0.035)\end{array}$ & $\begin{array}{l}-0.029 \\
(0.030)\end{array}$ & $\begin{array}{l}0.048 \\
(0.031)\end{array}$ & $\begin{array}{l}-0.029 \\
(0.030)\end{array}$ \\
\hline$\Delta$ NT*Credit $(-1)$ & & $\begin{array}{l}0.006 \\
(0.007)\end{array}$ & & $\begin{array}{l}0.009 \\
(0.007)\end{array}$ \\
\hline$\Delta$ Output $(-1)$ & $\begin{array}{l}0.045 \\
(0.064)\end{array}$ & $\begin{array}{l}0.036 \\
(0.041)\end{array}$ & $\begin{array}{l}0.034 \\
(0.069)\end{array}$ & $\begin{array}{l}0.031 \\
(0.044)\end{array}$ \\
\hline$\Delta$ Trade Openness & $\begin{array}{l}-0.290^{* * *} \\
(0.055)\end{array}$ & $\begin{array}{l}-0.247 * * * \\
(0.040)\end{array}$ & $\begin{array}{l}-0.300^{* * *} \\
(0.059)\end{array}$ & $\begin{array}{l}-0.252^{* * *} \\
(0.041)\end{array}$ \\
\hline$\Delta$ Exchange Rate & $\begin{array}{l}0.171 \\
(0.208)\end{array}$ & $\begin{array}{l}0.232 \\
(0.145)\end{array}$ & $\begin{array}{l}0.214 \\
(0.185)\end{array}$ & $\begin{array}{l}0.255^{*} \\
(0.139)\end{array}$ \\
\hline Crisis & $\begin{array}{l}-0.026^{* *} \\
(0.010)\end{array}$ & $\begin{array}{l}-0.029^{* * *} \\
(0.007)\end{array}$ & $\begin{array}{l}-0.026^{* * *} \\
(0.007)\end{array}$ & $\begin{array}{l}-0.029^{* * *} \\
(0.006)\end{array}$ \\
\hline $\begin{array}{l}\text { Long-Term Coeff. } \\
\text { ECC }\end{array}$ & $\begin{array}{l}-0.177^{* * * *} \\
(0.055)\end{array}$ & $\begin{array}{l}-0.225^{* * *} \\
(0.046)\end{array}$ & $\begin{array}{l}-0.196 * * * \\
(0.053)\end{array}$ & $\begin{array}{l}-0.227^{* * *} \\
(0.045)\end{array}$ \\
\hline Credit & $\begin{array}{l}0.331^{* * *} \\
(0.098)\end{array}$ & $\begin{array}{l}-0.019 \\
(0.176)\end{array}$ & $\begin{array}{l}0.415^{* * *} \\
(0.091)\end{array}$ & $\begin{array}{l}-0.019 \\
(0.176)\end{array}$ \\
\hline $\mathrm{NT}^{*}$ Credit & & $\begin{array}{l}0.081 * * * \\
(0.024)\end{array}$ & & $\begin{array}{l}0.091 * * * \\
(0.027)\end{array}$ \\
\hline Trade Openness & $\begin{array}{l}-0.858^{* *} \\
(0.348)\end{array}$ & $\begin{array}{l}-0.943^{* * *} \\
(0.232)\end{array}$ & $\begin{array}{l}-0.810^{* *} \\
(0.321)\end{array}$ & $\begin{array}{l}-0.916^{* * *} \\
(0.226)\end{array}$ \\
\hline Exchange Rate & $\begin{array}{l}1.794 \\
(1.738)\end{array}$ & $\begin{array}{l}1.880^{*} \\
(1.074)\end{array}$ & $\begin{array}{l}1.516 \\
(1.635)\end{array}$ & $\begin{array}{l}1.603 \\
(1.044)\end{array}$ \\
\hline $\mathrm{N}$ & 757 & 1,514 & 639 & 1,420 \\
\hline
\end{tabular}




\section{Additional Figures, Tables and Robustness Tests}

(Not for publication) 


\section{Appendix B Additional Figures and Tables}
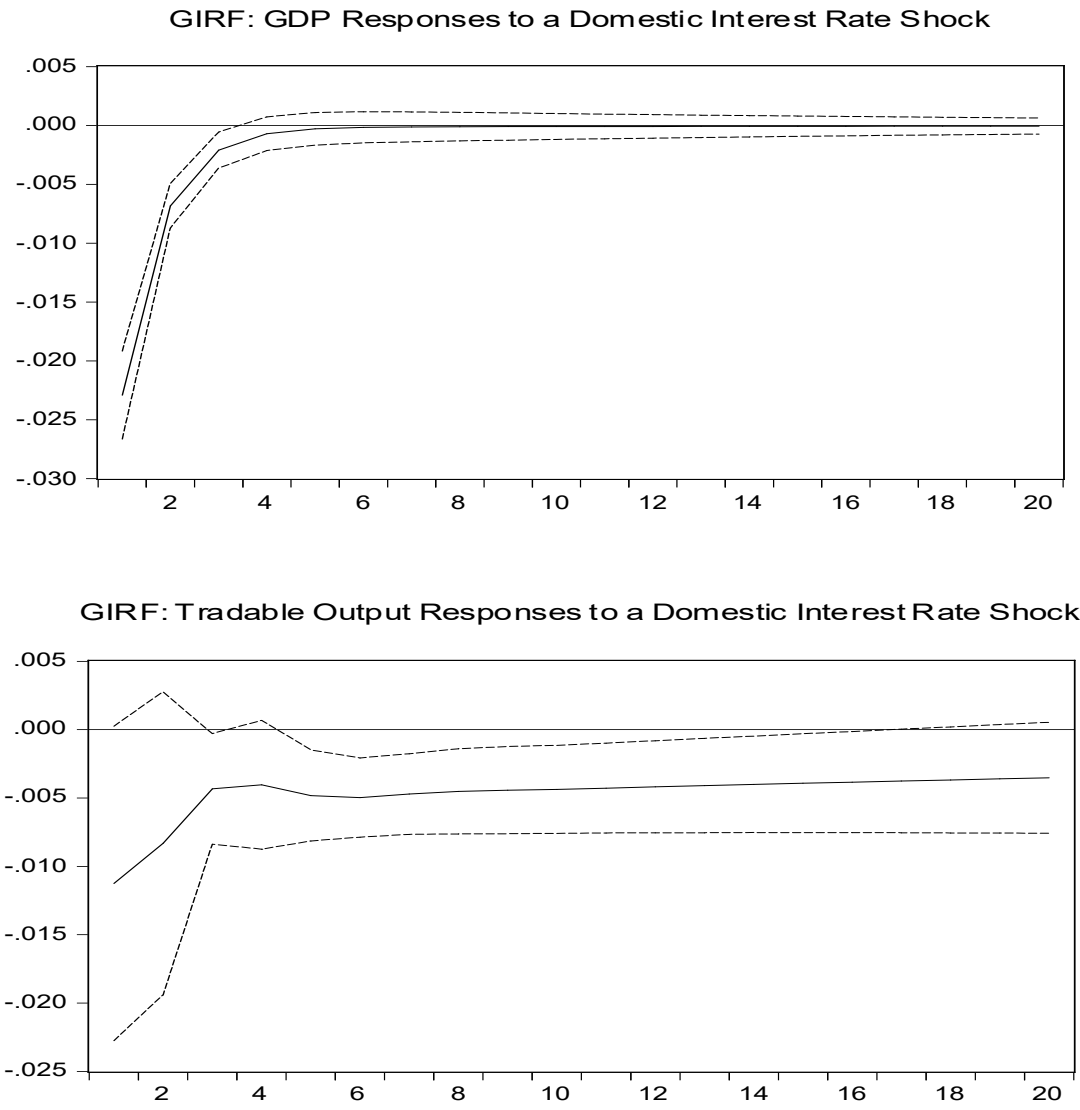

GIRF: Non-Tradable Output Responses to a Domestic Interest Rate Shock

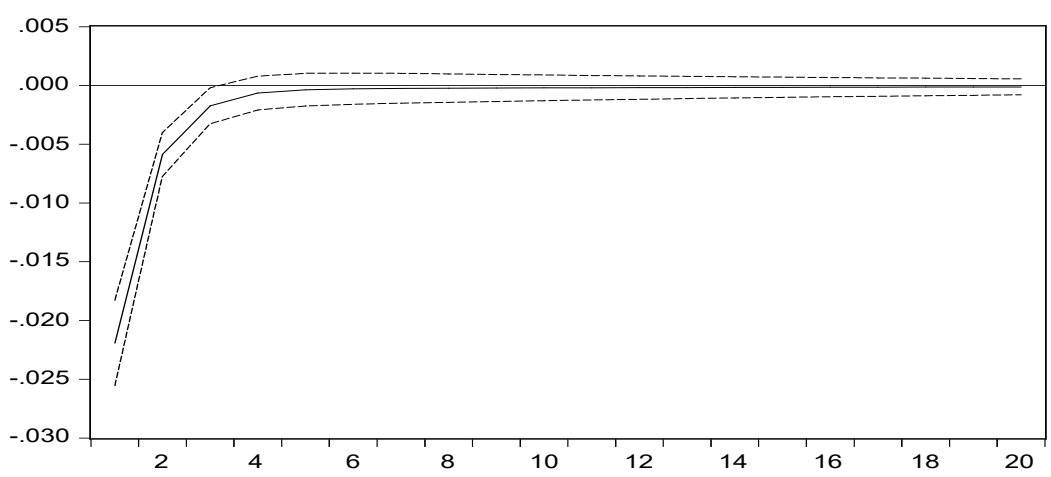

Figure B.1: Emerging Markets: GIRs to a Domestic Interest Rate Shock 


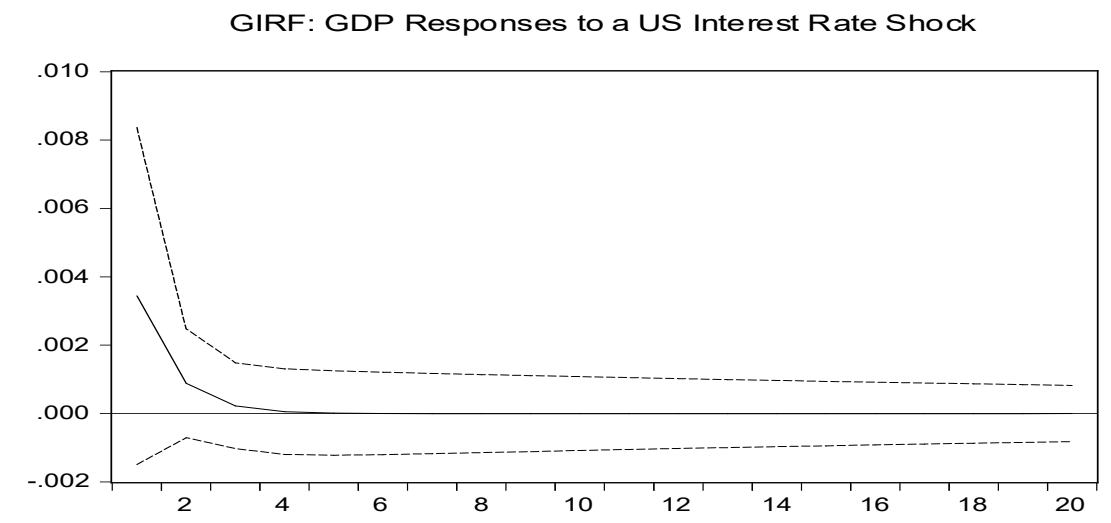

GIRF: Tradable Output Responses to a US Interest Rate Shock

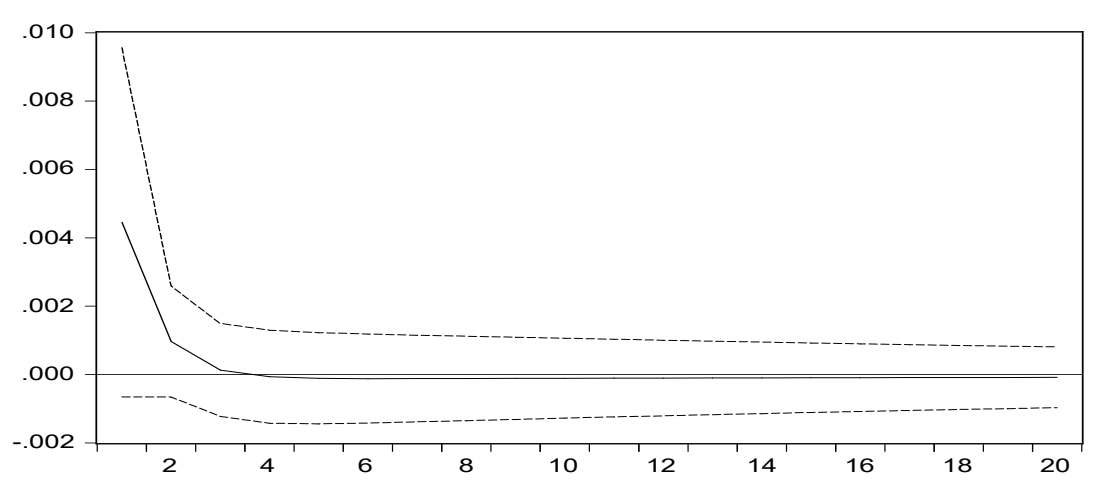

GIRF: Non-Tradable Output Responses to a US Interest Rate Shock

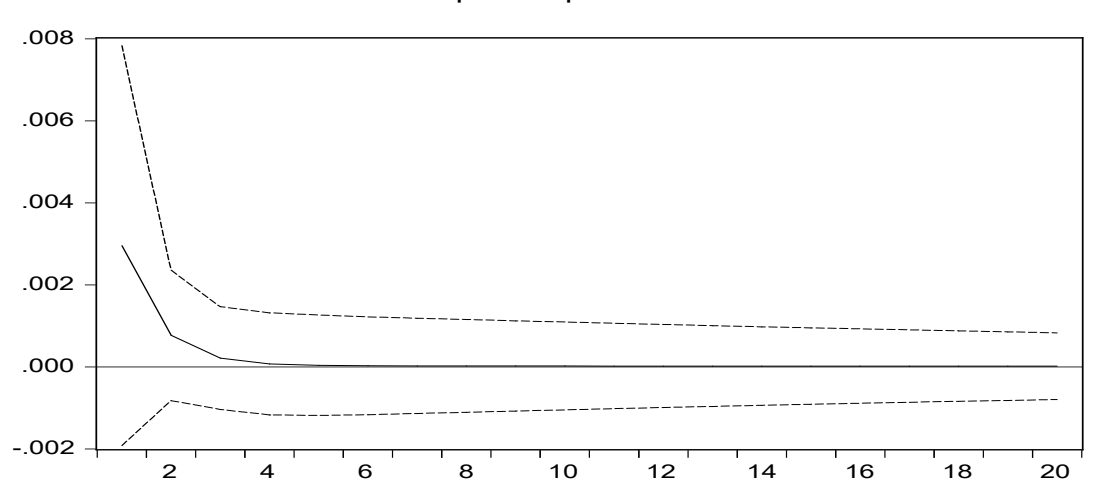

Figure B.2: Emerging Markets: GIRs to a U.S. Interest Rate Shock 


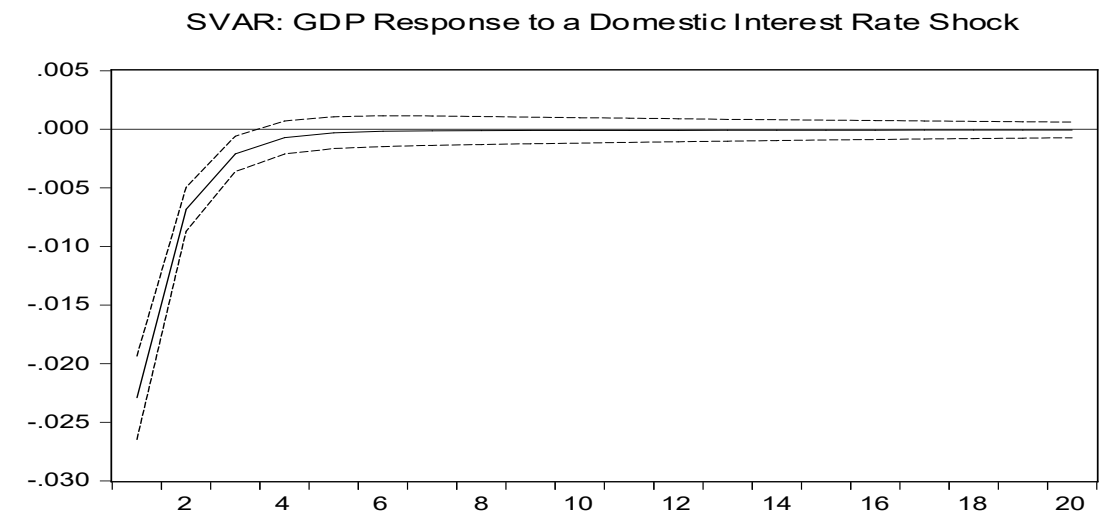

SVAR: Tradable Output Response to a Domestic Interest Rate Shock

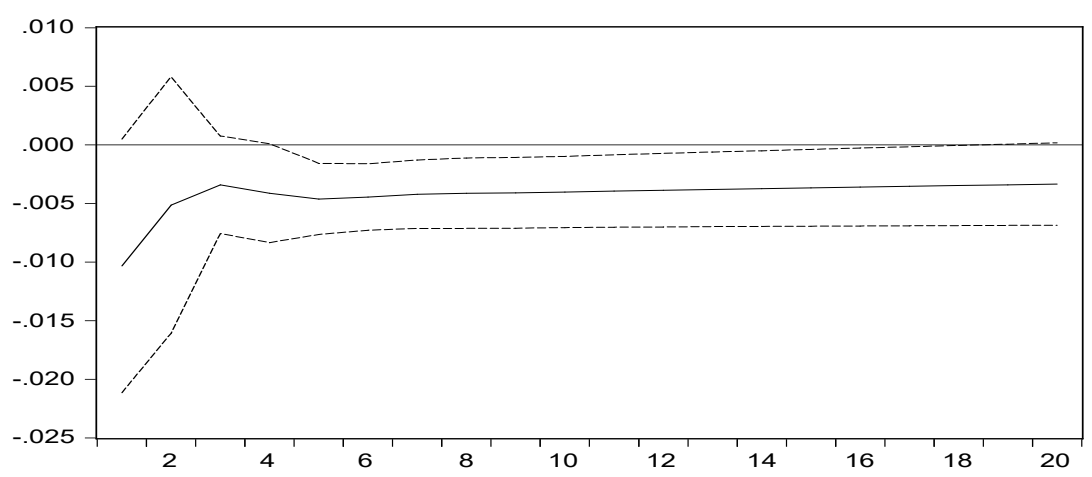

SVAR: Non-Tradable Output Response to a Domestic Interest Rate Shock

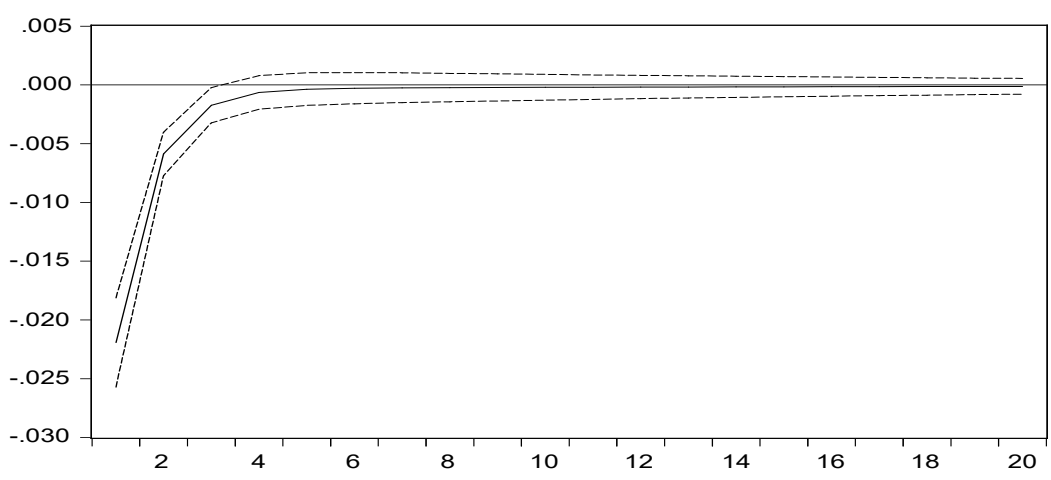

Figure B.3: Emerging Markets: SVAR, IRFs to a Domestic Interest Rate Shock 


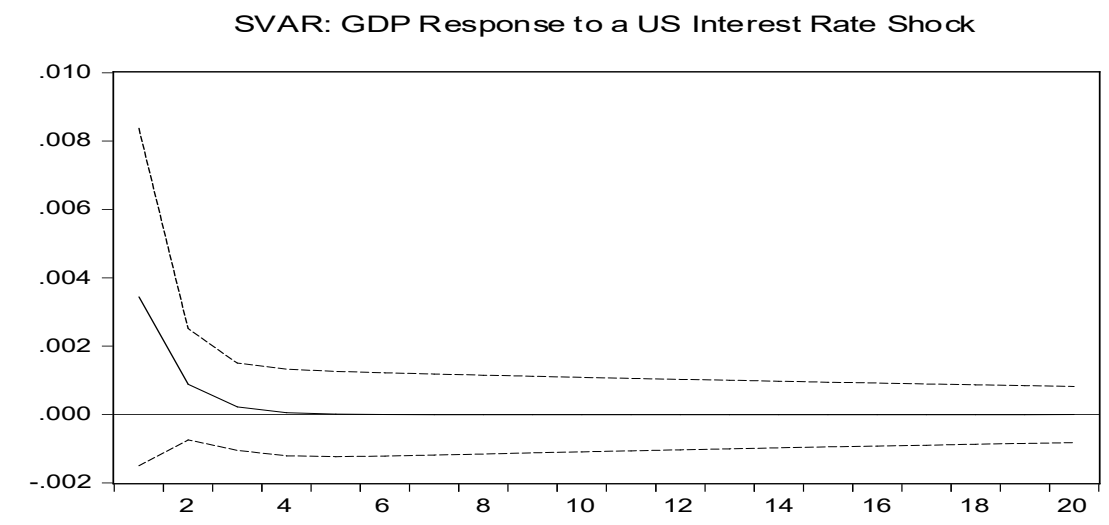

SVAR: Tradable Output Response to a US Interest Rate Shock

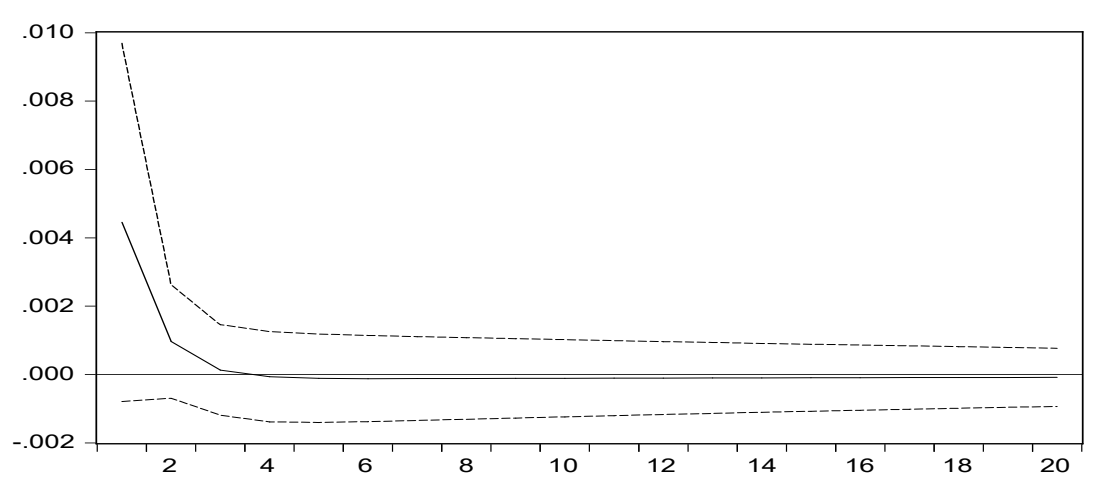

SVAR: Non-Tradable Output Response to a US Interest Rate Shock

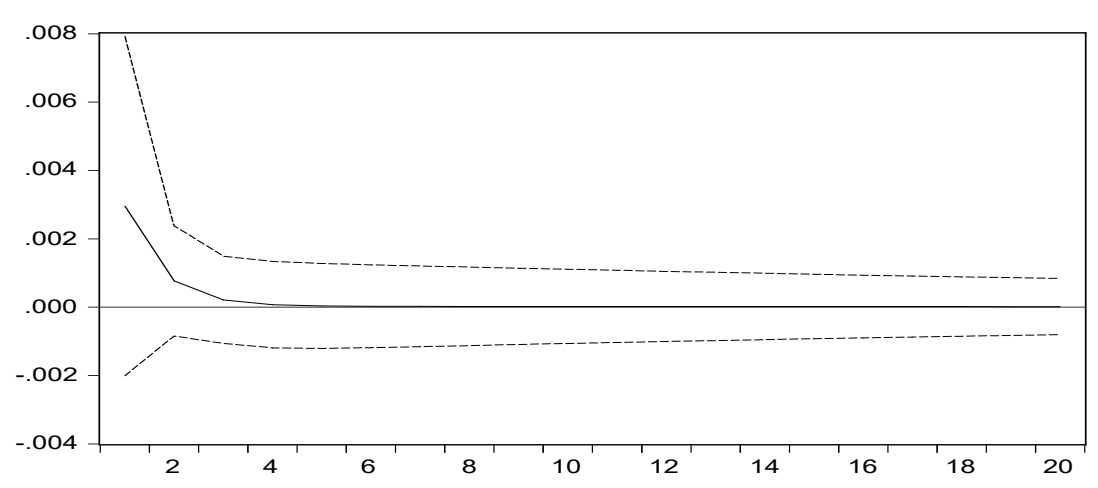

Figure B.4: Emerging Markets: SVAR, IRFs to a U.S. Interest Rate Shock 


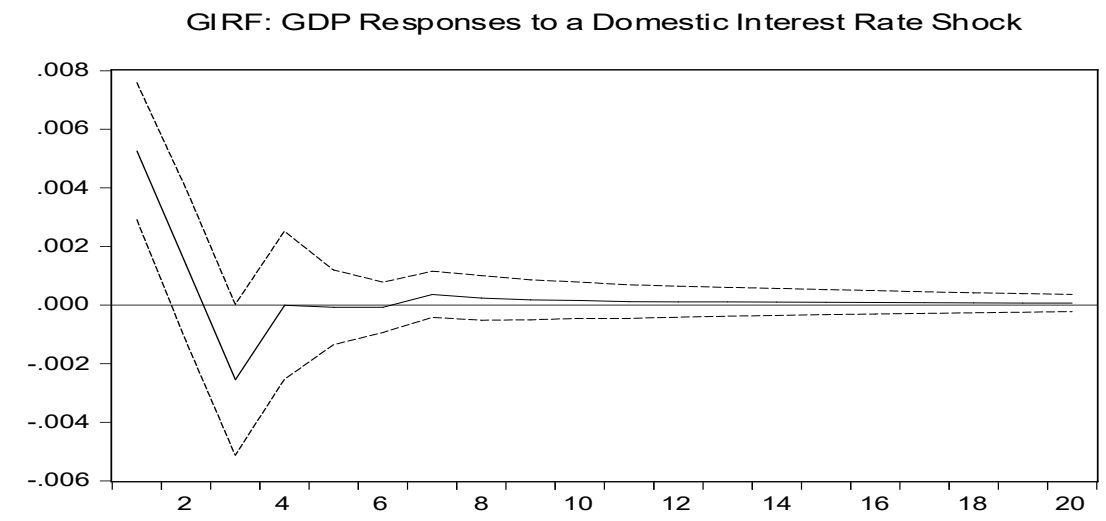

GIRF: Tradable Output Responses to a Domestic Interest Rate Shock

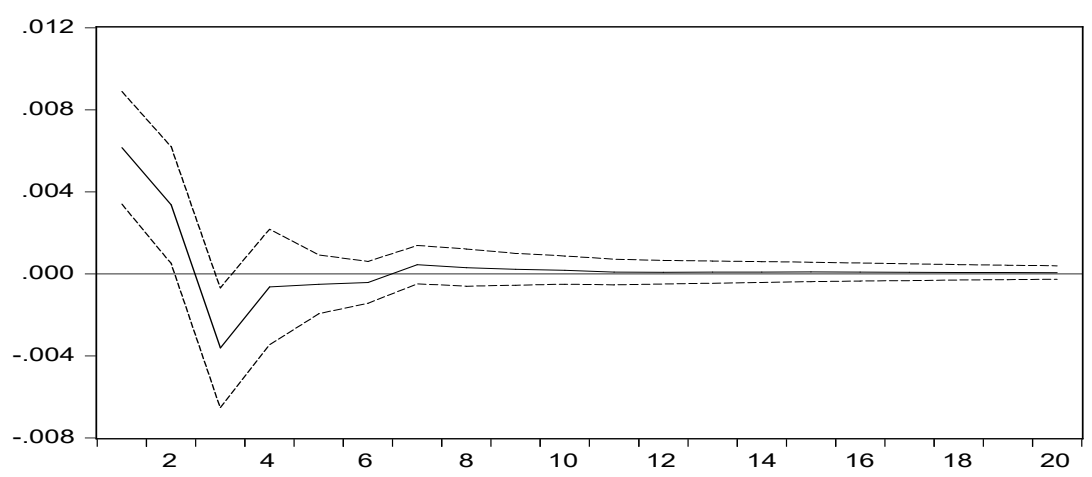

GIRF: Non-Tradable Output Responses to a Domestic Interest Rate Shock

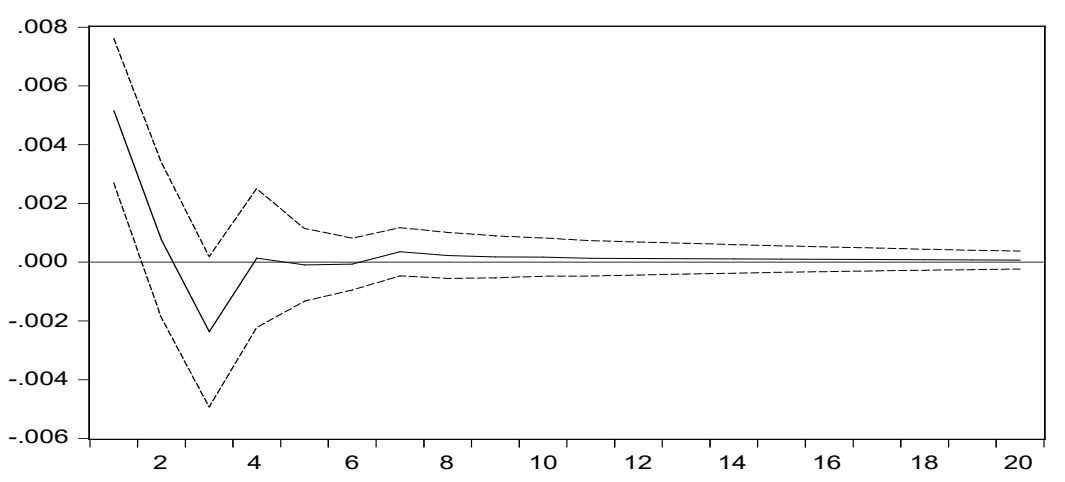

Figure B.5: Developed Open Economies: GIRs to a Domestic Interest Rate Shock 

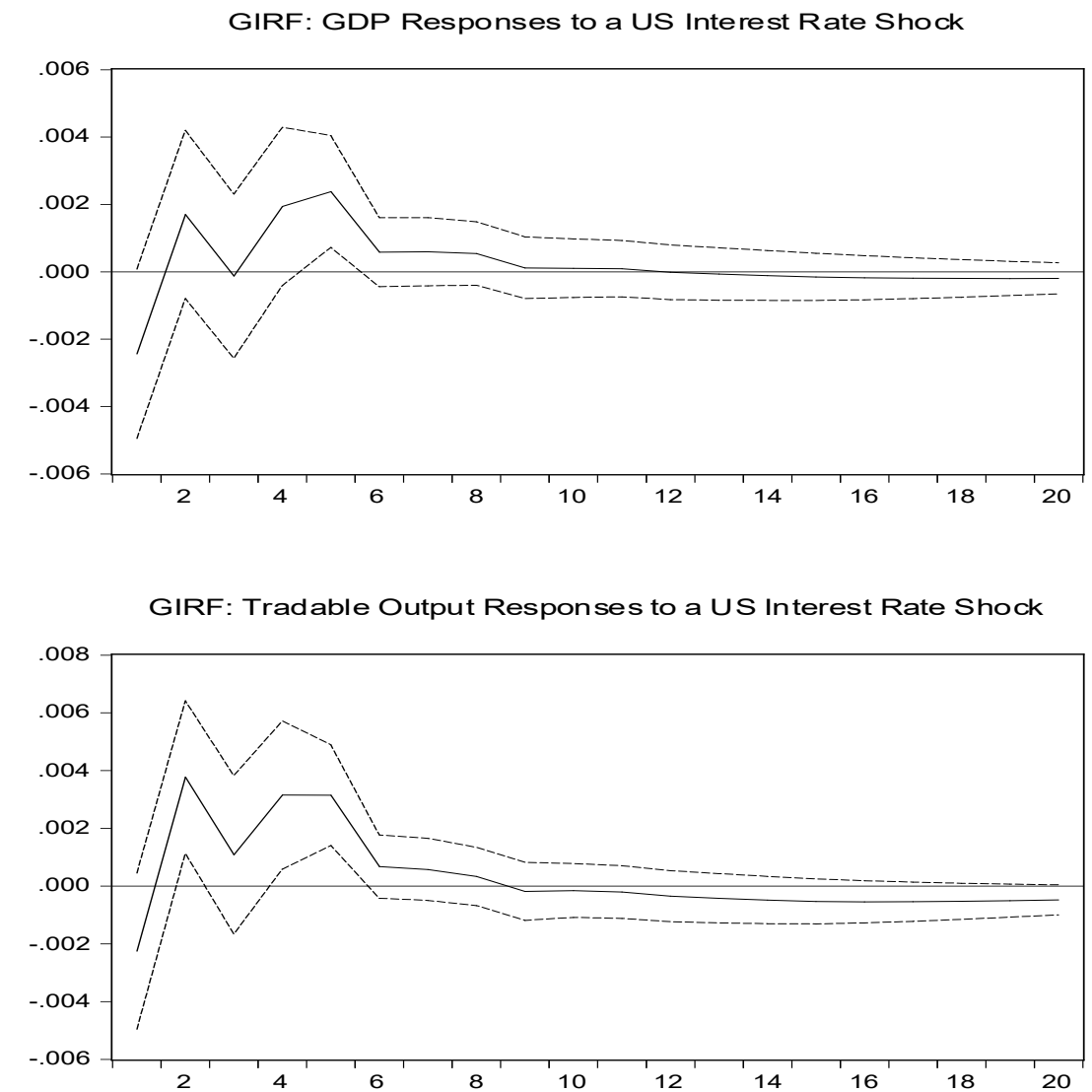

GIRF: Non-Tradable Output Responses to a US Interest Rate Shock

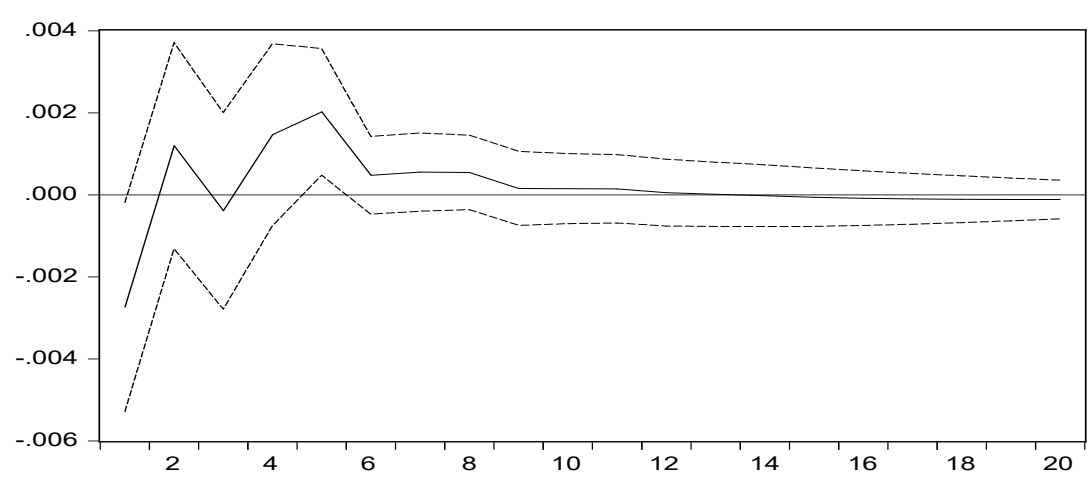

Figure B.6: Developed Open Economies: GIRs to a U.S. Interest Rate Shock 


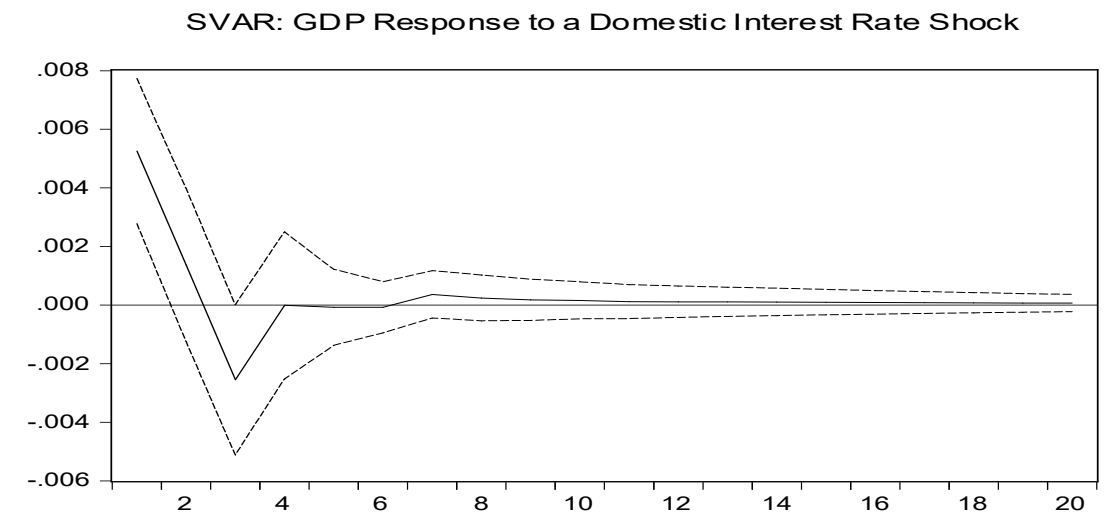

SVAR: Tradable Output Responso to a Domestic Interest Rate Shock

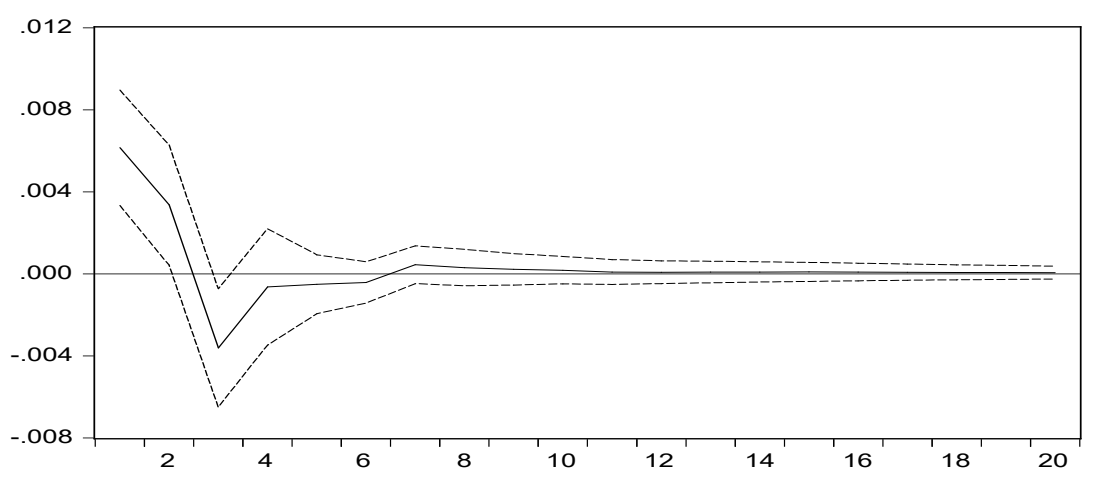

SVAR: Non-Tradable Output Response to a Domestic Interest Rate Shock

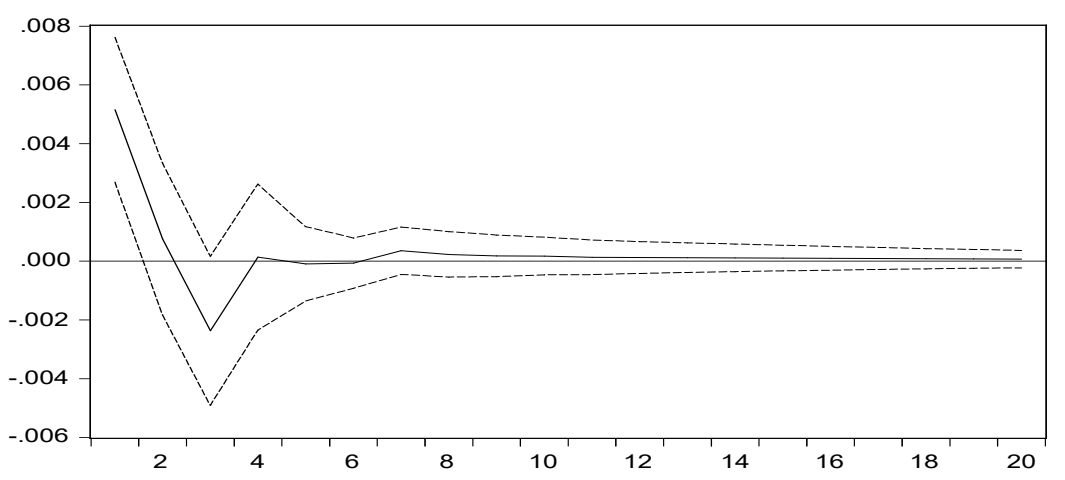

Figure B.7: Developed Open Economies: SVAR, IRFs to a Domestic Interest Rate Shock 


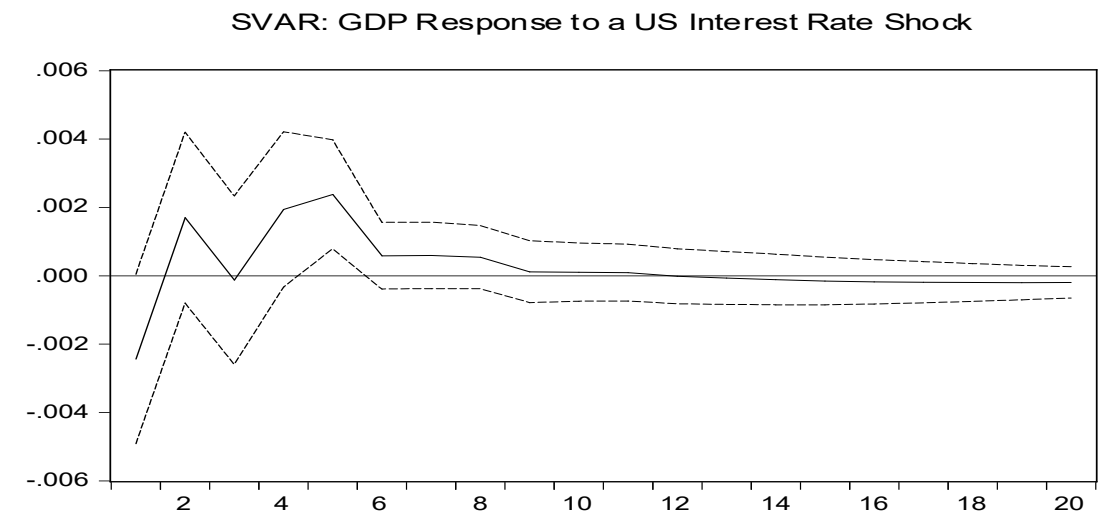

SVAR: Tradable Output Response to a US Interest Rate Shock

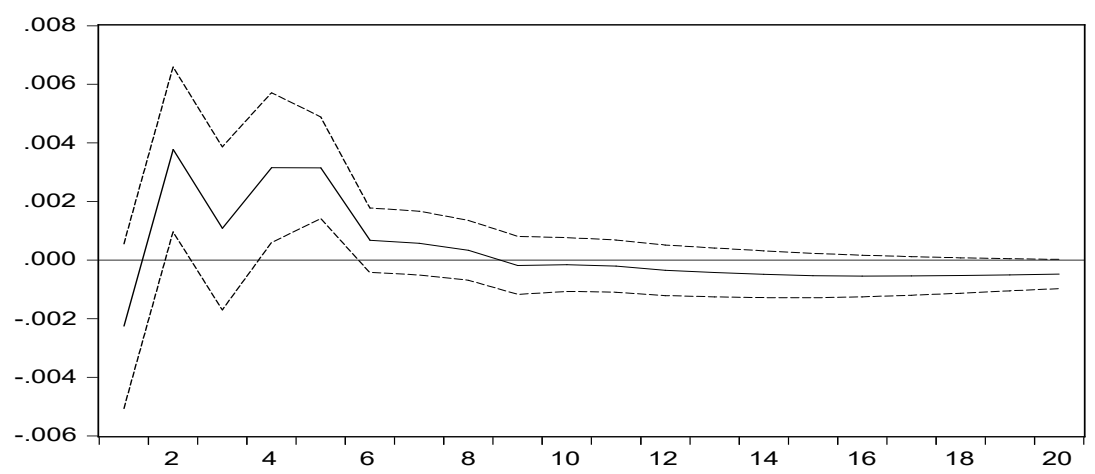

SVAR: Non-Tradable Output Response to a US Interest Rate Shock

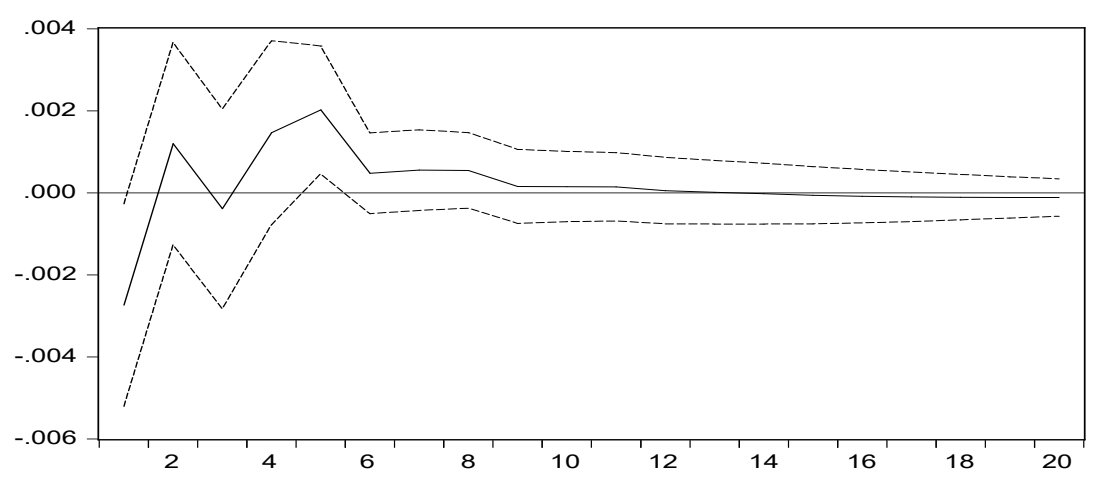

Figure B.8: Developed Open Economies: SVAR, IRFs to a U.S. Interest Rate Shock 
SVAR- IRFs: GDP Responses to a Domestic Interest Rate Shock
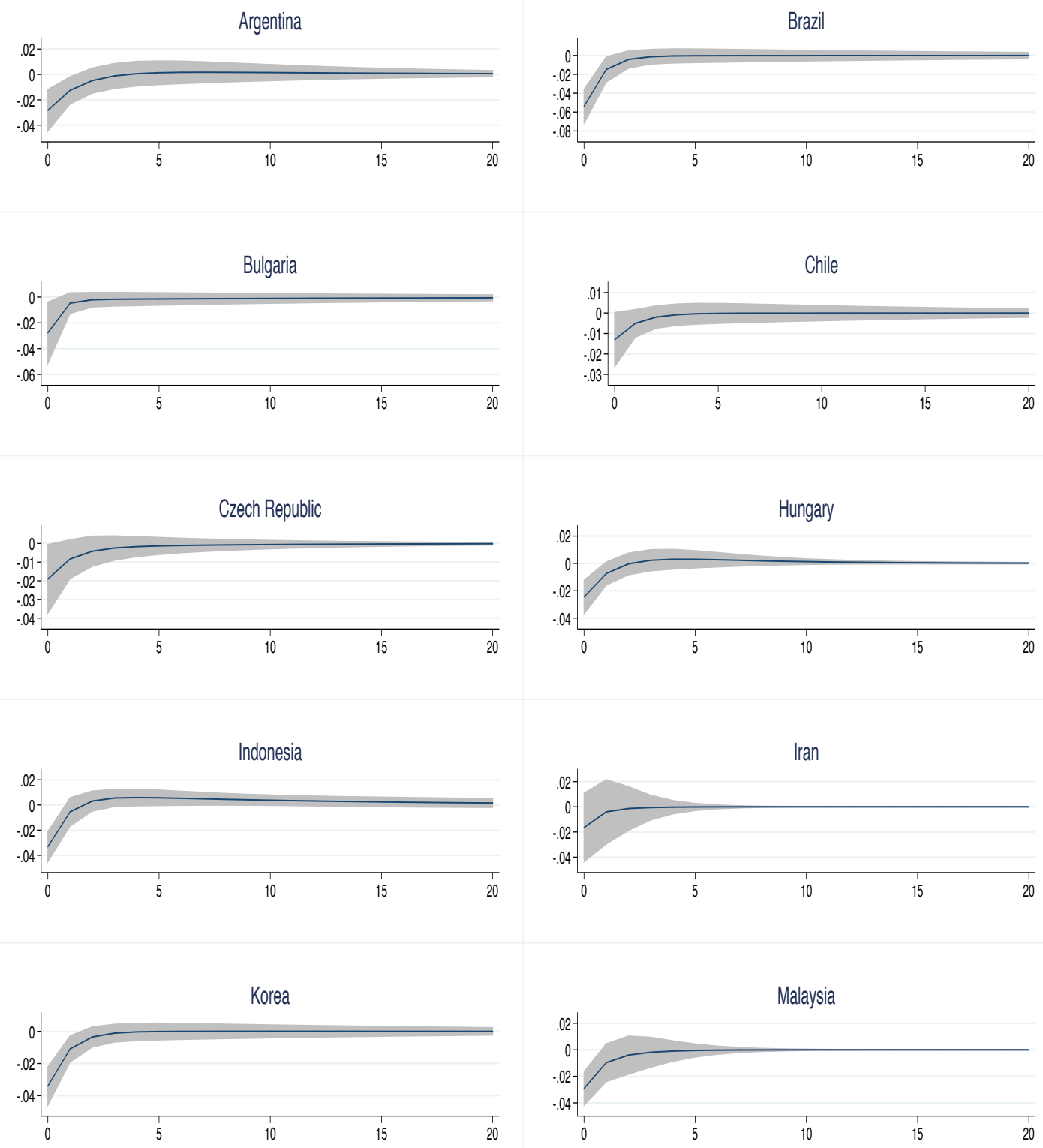

Figure B.9: Emerging Markets: SVAR. GDP Responses to a Domestic Interest Rate Shock 
SVAR- IRFs: GDP Responses to a Domestic Interest Rate Shock
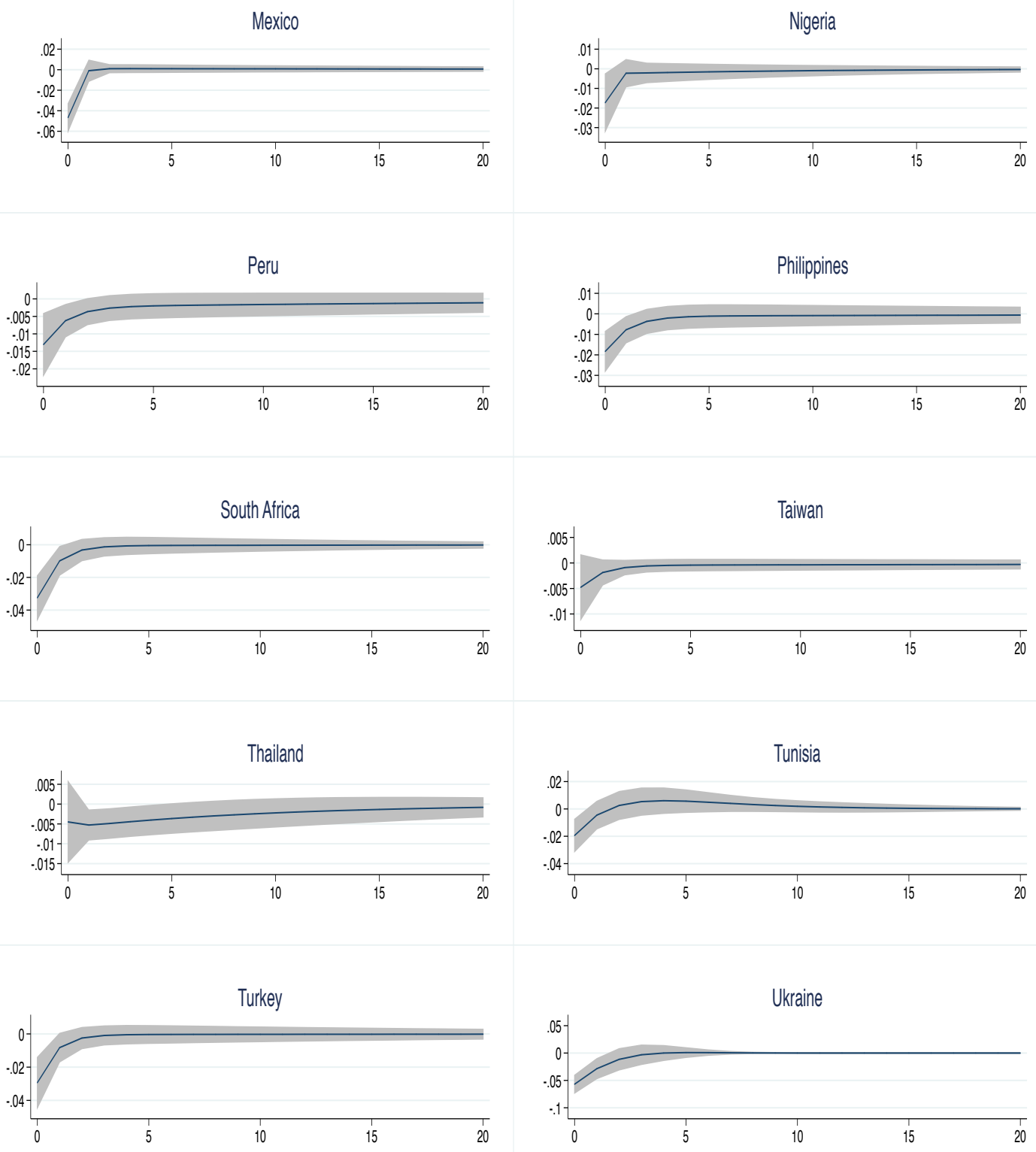

Figure B.10: Emerging Markets: SVAR. GDP Responses to a Domestic Interest Rate Shock 
SVAR- IRFs: Non-Tradable Output Responses to a Domestic Interest Rate Shock
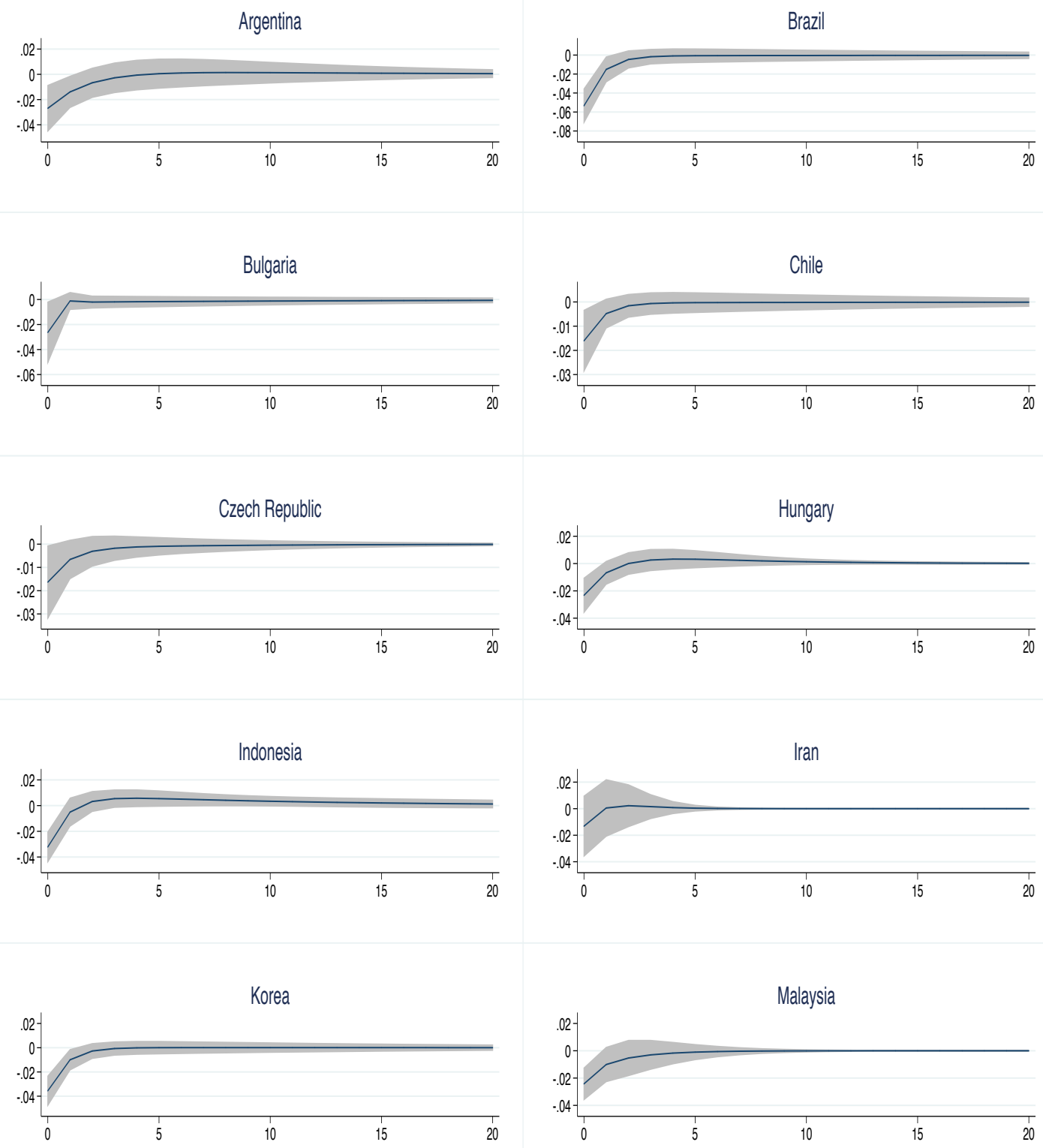

Figure B.11: Emerging Markets: SVAR. Non-Tradable Output Responses to a Domestic Interest Rate Shock 
SVAR- IRFs: Non-Tradable Output Responses to a Domestic Interest Rate Shock
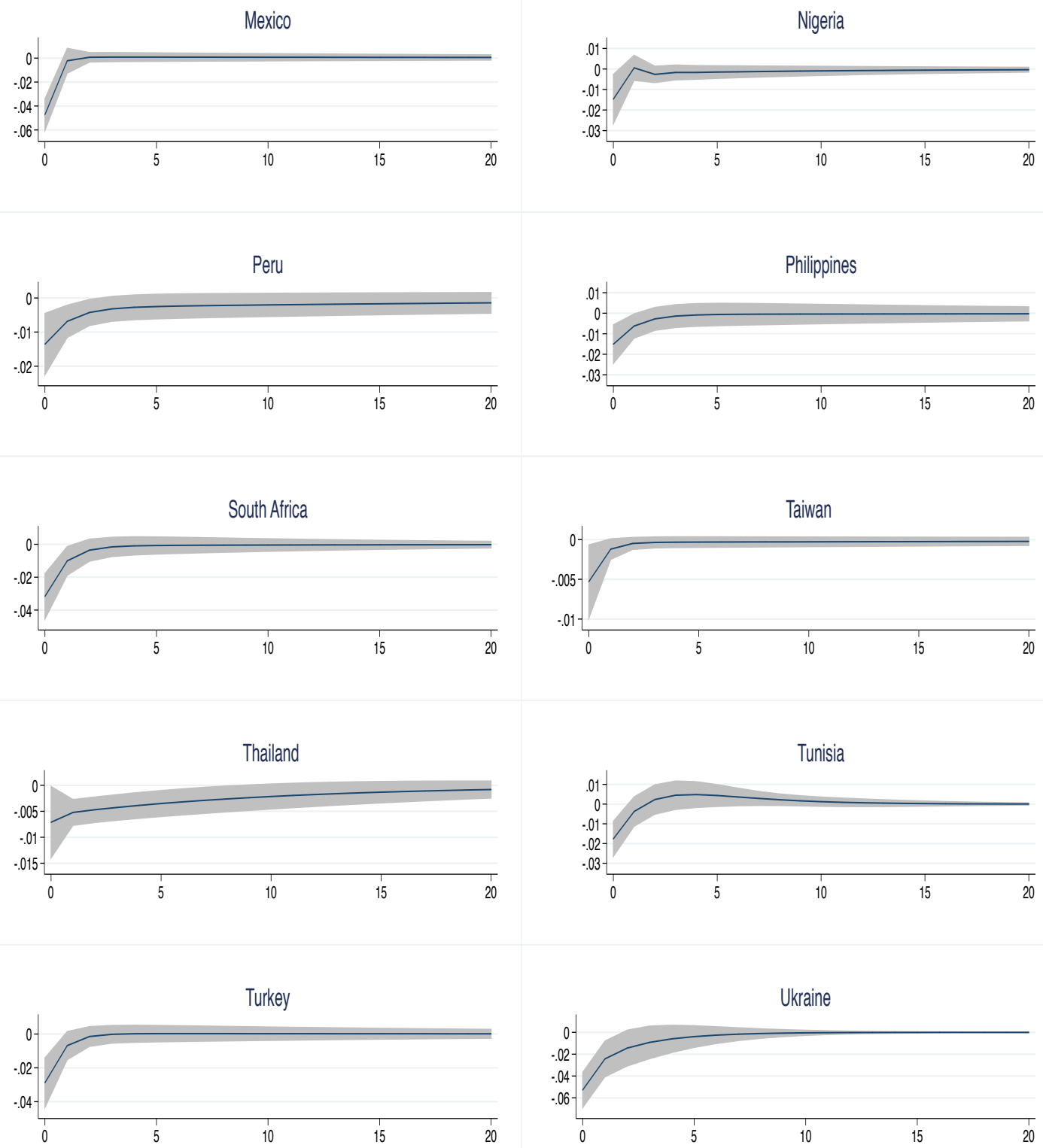

Figure B.12: Emerging Markets: SVAR. Non-Tradable Output Responses to a Domestic Interest Rate Shock 
Table B.1: Emerging Markets: Panel VAR

\begin{tabular}{|c|c|c|c|}
\hline & \multicolumn{3}{|c|}{ Panel A: Domestic Interest Rate } \\
\hline & $\begin{array}{l}\text { GDP } \\
(1)\end{array}$ & $\begin{array}{l}\text { Tradable } \\
(2)\end{array}$ & $\begin{array}{l}\text { Non- } \\
\text { Tradable } \\
(3)\end{array}$ \\
\hline $\begin{array}{l}\text { Dependent Variable: Output Growth } \\
\text { Interest Rate }(-1)\end{array}$ & $\begin{array}{l}-0.067^{* *} \\
(0.028)\end{array}$ & $\begin{array}{l}-0.059 \\
(0.054)\end{array}$ & $\begin{array}{l}-0.064^{* *} \\
(0.031)\end{array}$ \\
\hline$\Delta$ Output $(-1)$ & $\begin{array}{l}0.318^{* * *} \\
(0.052)\end{array}$ & $\begin{array}{l}0.266^{* * *} \\
(0.047)\end{array}$ & $\begin{array}{l}0.271^{* * *} \\
(0.085)\end{array}$ \\
\hline $\begin{array}{l}\text { Dependent Variable: Interest Rate } \\
\text { Interest Rate }(-1)\end{array}$ & $\begin{array}{l}0.970^{* * *} \\
(0.008)\end{array}$ & $\begin{array}{l}0.970^{* * *} \\
(0.009)\end{array}$ & $\begin{array}{l}0.970^{* * *} \\
(0.007)\end{array}$ \\
\hline$\Delta$ Output $(-1)$ & $\begin{array}{l}-0.014 \\
(0.012)\end{array}$ & $\begin{array}{l}-0.011 \\
(0.010)\end{array}$ & $\begin{array}{l}-0.016 \\
(0.012)\end{array}$ \\
\hline \multirow[t]{3}{*}{$\mathrm{N}$} & 1186 & 1186 & 1186 \\
\hline & \multicolumn{3}{|c|}{ Panel B: U.S. Interest Rate } \\
\hline & $\begin{array}{l}\text { GDP } \\
(1)\end{array}$ & $\begin{array}{l}\text { Tradable } \\
(2)\end{array}$ & $\begin{array}{l}\text { Non- } \\
\text { Tradable } \\
(3) \\
\end{array}$ \\
\hline $\begin{array}{l}\text { Dependent Variable: Output Growth } \\
\text { Interest Rate U.S. }(-1)\end{array}$ & $\begin{array}{l}-0.057 \\
(0.050)\end{array}$ & $\begin{array}{l}-0.080^{*} \\
(0.046)\end{array}$ & $\begin{array}{l}-0.055 \\
(0.060)\end{array}$ \\
\hline$\Delta \operatorname{GDP}(-1)$ & $\begin{array}{l}0.283^{* * *} \\
(0.083)\end{array}$ & $\begin{array}{l}0.264^{* * *} \\
(0.080)\end{array}$ & $\begin{array}{l}0.274^{* * *} \\
(0.080)\end{array}$ \\
\hline $\begin{array}{l}\text { Dependent Variable: Interest Rate } \\
\text { Interest Rate U.S. (-1) }\end{array}$ & $\begin{array}{l}0.988^{* * *} \\
(0.003)\end{array}$ & $\begin{array}{l}0.988^{* * *} \\
(0.003)\end{array}$ & $\begin{array}{l}0.988^{* * *} \\
(0.003)\end{array}$ \\
\hline$\Delta$ Output $(-1)$ & $\begin{array}{l}-0.000 \\
(0.001)\end{array}$ & $\begin{array}{l}0.000 \\
(0.001)\end{array}$ & $\begin{array}{l}-0.001 \\
(0.001)\end{array}$ \\
\hline $\mathrm{N}$ & 1,567 & 1,567 & 1,567 \\
\hline
\end{tabular}


Table B.2: Developed Open Economies: Panel VAR

\begin{tabular}{|c|c|c|c|}
\hline & \multicolumn{3}{|c|}{ Domestic Interest Rate } \\
\hline & $\begin{array}{l}\text { GDP } \\
(1)\end{array}$ & $\begin{array}{l}\text { Tradable } \\
(2)\end{array}$ & $\begin{array}{l}\text { Non- } \\
\text { Tradable } \\
(3)\end{array}$ \\
\hline $\begin{array}{l}\text { Dependent Variable: Output Growth } \\
\text { Interest Rate }(-1)\end{array}$ & $\begin{array}{l}-0.031 \\
(0.262)\end{array}$ & $\begin{array}{l}0.391 \\
(0.286)\end{array}$ & $\begin{array}{l}-0.146 \\
(0.265)\end{array}$ \\
\hline Interest Rate $(-2)$ & $\begin{array}{l}-0.423 \\
(0.349)\end{array}$ & $\begin{array}{l}-1.173^{* * *} \\
(0.397)\end{array}$ & $\begin{array}{l}-0.251 \\
(0.350)\end{array}$ \\
\hline Interest Rate $(-3)$ & $\begin{array}{l}0.730^{*} \\
(0.401)\end{array}$ & $\begin{array}{l}1.099^{* *} \\
(0.441)\end{array}$ & $\begin{array}{l}0.631 \\
(0.402)\end{array}$ \\
\hline Interest Rate $(-4)$ & $\begin{array}{l}-0.182 \\
(0.268)\end{array}$ & $\begin{array}{l}-0.221 \\
(0.294)\end{array}$ & $\begin{array}{l}-0.151 \\
(0.274)\end{array}$ \\
\hline$\Delta$ Output $(-1)$ & $\begin{array}{l}0.332^{* * *} \\
(0.032)\end{array}$ & $\begin{array}{l}0.285^{* * *} \\
(0.035)\end{array}$ & $\begin{array}{l}0.320^{* * *} \\
(0.032)\end{array}$ \\
\hline$\Delta$ Output $(-2)$ & $\begin{array}{l}-0.132^{* * *} \\
(0.037)\end{array}$ & $\begin{array}{l}-0.110^{* * *} \\
(0.036)\end{array}$ & $\begin{array}{l}-0.114^{* * *} \\
(0.036)\end{array}$ \\
\hline$\Delta$ Output $(-3)$ & $\begin{array}{l}0.002 \\
(0.028)\end{array}$ & $\begin{array}{l}-0.028 \\
(0.029)\end{array}$ & $\begin{array}{l}0.021 \\
(0.029)\end{array}$ \\
\hline$\Delta$ Output $(-4)$ & $\begin{array}{l}-0.078^{* *} \\
(0.033)\end{array}$ & $\begin{array}{l}-0.099^{* * *} \\
(0.033)\end{array}$ & $\begin{array}{l}-0.076^{* *} \\
(0.032)\end{array}$ \\
\hline $\begin{array}{l}\text { Dependent Variable: Interest Rate } \\
\text { Interest Rate }(-1)\end{array}$ & $\begin{array}{l}1.099^{* * *} \\
(0.057)\end{array}$ & $\begin{array}{l}1.101^{* * *} \\
(0.056)\end{array}$ & $\begin{array}{l}1.102^{* * *} \\
(0.057)\end{array}$ \\
\hline Interest Rate $(-2)$ & $\begin{array}{l}-0.053 \\
(0.067)\end{array}$ & $\begin{array}{l}-0.064 \\
(0.068)\end{array}$ & $\begin{array}{l}-0.054 \\
(0.067)\end{array}$ \\
\hline Interest Rate $(-3)$ & $\begin{array}{l}-0.013 \\
(0.071)\end{array}$ & $\begin{array}{l}-0.009 \\
(0.069)\end{array}$ & $\begin{array}{l}-0.016 \\
(0.071)\end{array}$ \\
\hline Interest Rate $(-4)$ & $\begin{array}{l}-0.076^{* *} \\
(0.036)\end{array}$ & $\begin{array}{l}-0.070^{*} \\
(0.036)\end{array}$ & $\begin{array}{l}-0.074^{* *} \\
(0.036)\end{array}$ \\
\hline$\Delta$ Output $(-1)$ & $\begin{array}{l}0.017^{* * *} \\
(0.006)\end{array}$ & $\begin{array}{l}0.015^{* * *} \\
(0.005)\end{array}$ & $\begin{array}{l}0.016^{* * *} \\
(0.006)\end{array}$ \\
\hline$\Delta$ Output $(-2)$ & $\begin{array}{l}0.009^{*} \\
(0.004)\end{array}$ & $\begin{array}{l}0.008^{* *} \\
(0.004)\end{array}$ & $\begin{array}{l}0.008^{*} \\
(0.005)\end{array}$ \\
\hline$\Delta$ Output $(-3)$ & $\begin{array}{l}-0.011^{* * *} \\
(0.004)\end{array}$ & $\begin{array}{l}-0.009^{* * *} \\
(0.003)\end{array}$ & $\begin{array}{l}-0.011^{* *} \\
(0.004)\end{array}$ \\
\hline.$\Delta$ Output $(-4)$ & $\begin{array}{l}0.005 \\
(0.004)\end{array}$ & $\begin{array}{l}0.004 \\
(0.003)\end{array}$ & $\begin{array}{l}0.004 \\
(0.004)\end{array}$ \\
\hline $\mathrm{N}$ & 1,230 & 1,230 & 1,230 \\
\hline
\end{tabular}


Table B.3: Developed Open Economies: Panel VAR

\begin{tabular}{|c|c|c|c|}
\hline & \multicolumn{3}{|c|}{ U.S. Interest Rate } \\
\hline & $\begin{array}{l}\text { GDP } \\
(1)\end{array}$ & $\begin{array}{l}\text { Tradable } \\
(2)\end{array}$ & $\begin{array}{l}\text { Non- } \\
\text { Tradable } \\
(3)\end{array}$ \\
\hline $\begin{array}{l}\text { Dependent Variable: Output Growth } \\
\text { Interest Rate }(-1)\end{array}$ & $\begin{array}{l}0.635^{*} \\
(0.337)\end{array}$ & $\begin{array}{l}1.151^{* * * *} \\
(0.391)\end{array}$ & $\begin{array}{l}0.523 \\
(0.331)\end{array}$ \\
\hline Interest Rate $(-2)$ & $\begin{array}{l}-1.308^{* *} \\
(0.561)\end{array}$ & $\begin{array}{l}-1.817^{* * *} \\
(0.633)\end{array}$ & $\begin{array}{l}-1.161^{* *} \\
(0.554)\end{array}$ \\
\hline Interest Rate $(-3)$ & $\begin{array}{l}1.435^{*} \\
(0.734)\end{array}$ & $\begin{array}{l}1.682^{* *} \\
(0.827)\end{array}$ & $\begin{array}{l}1.266^{*} \\
(0.717)\end{array}$ \\
\hline Interest Rate $(-4)$ & $\begin{array}{l}-0.718 \\
(0.499)\end{array}$ & $\begin{array}{l}-0.976^{*} \\
(0.566)\end{array}$ & $\begin{array}{l}-0.588 \\
(0.487)\end{array}$ \\
\hline$\Delta$ GDP $(-1)$ & $\begin{array}{l}0.334^{* * *} \\
(0.031)\end{array}$ & $\begin{array}{l}0.283^{* * *} \\
(0.034)\end{array}$ & $\begin{array}{l}0.322^{* * *} \\
(0.032)\end{array}$ \\
\hline$\Delta \operatorname{GDP}(-2)$ & $\begin{array}{l}-0.138^{* * *} \\
(0.039)\end{array}$ & $\begin{array}{l}-0.113^{* * *} \\
(0.038)\end{array}$ & $\begin{array}{l}-0.121^{* * *} \\
(0.038)\end{array}$ \\
\hline$\Delta \operatorname{GDP}(-3)$ & $\begin{array}{l}-0.012 \\
(0.029)\end{array}$ & $\begin{array}{l}-0.041 \\
(0.030)\end{array}$ & $\begin{array}{l}0.008 \\
(0.030)\end{array}$ \\
\hline$\Delta$ GDP $(-4)$ & $\begin{array}{l}-0.061^{* *} \\
(0.029)\end{array}$ & $\begin{array}{l}-0.091^{* * *} \\
(0.030)\end{array}$ & $\begin{array}{l}-0.061^{* *} \\
(0.029)\end{array}$ \\
\hline $\begin{array}{l}\text { Dependent Variable: Interest Rate } \\
\text { Interest Rate }(-1)\end{array}$ & $\begin{array}{l}1.337^{* * *} \\
(0.033)\end{array}$ & $\begin{array}{l}1.333^{* * *} \\
(0.034)\end{array}$ & $\begin{array}{l}1.338^{* * *} \\
(0.032)\end{array}$ \\
\hline Interest Rate $(-2)$ & $\begin{array}{l}-0.354^{* * *} \\
(0.051)\end{array}$ & $\begin{array}{l}-0.339^{* * *} \\
(0.053)\end{array}$ & $\begin{array}{l}-0.357^{* * *} \\
(0.051)\end{array}$ \\
\hline Interest Rate $(-3)$ & $\begin{array}{l}0.253^{* * *} \\
(0.045)\end{array}$ & $\begin{array}{l}0.232^{* * * *} \\
(0.045)\end{array}$ & $\begin{array}{l}0.256^{* * *} \\
(0.045)\end{array}$ \\
\hline Interest Rate $(-4)$ & $\begin{array}{l}-0.261^{* * *} \\
(0.030)\end{array}$ & $\begin{array}{l}-0.251^{* * *} \\
(0.030)\end{array}$ & $\begin{array}{l}-0.262^{* * *} \\
(0.030)\end{array}$ \\
\hline$\Delta \operatorname{GDP}(-1)$ & $\begin{array}{l}-0.013^{* * *} \\
(0.003)\end{array}$ & $\begin{array}{l}-0.010^{* * *} \\
(0.002)\end{array}$ & $\begin{array}{l}-0.013^{* * *} \\
(0.003)\end{array}$ \\
\hline$\Delta$ GDP $(-2)$ & $\begin{array}{l}0.009^{* * *} \\
(0.003)\end{array}$ & $\begin{array}{l}0.005^{* *} \\
(0.002)\end{array}$ & $\begin{array}{l}0.009^{* * *} \\
(0.003)\end{array}$ \\
\hline$\Delta \operatorname{GDP}(-3)$ & $\begin{array}{l}-0.007^{* * *} \\
(0.002)\end{array}$ & $\begin{array}{l}-0.004^{*} \\
(0.002)\end{array}$ & $\begin{array}{l}-0.007 * * * \\
(0.002)\end{array}$ \\
\hline$\Delta \operatorname{GDP}(-4)$ & $\begin{array}{l}0.017^{* * *} \\
(0.002)\end{array}$ & $\begin{array}{l}0.010^{* * *} \\
(0.002)\end{array}$ & $\begin{array}{l}0.018^{* * *} \\
(0.002)\end{array}$ \\
\hline $\mathrm{N}$ & 1,230 & 1,230 & 1,230 \\
\hline
\end{tabular}


Table B.4: Panel VAR: Interest Rate and Output Growth- Robustness for NT Activities

\begin{tabular}{|c|c|c|c|c|}
\hline & \multicolumn{2}{|c|}{ Developed Open Economies } & \multicolumn{2}{|c|}{ Emerging Markets } \\
\hline & Non-Tradable & Non-Tradable & Non-Tradable & Non-Tradable \\
\hline & $\begin{array}{l}\text { Excluding Finance } \\
(1)\end{array}$ & $\begin{array}{l}\text { Excl. Fin. \& Gov. } \\
\text { Reg. Act. } \\
(2)\end{array}$ & $\begin{array}{l}\text { Excluding Finance } \\
(3)\end{array}$ & $\begin{array}{l}\text { Excl. Fin. \& Gov. } \\
\text { Reg. Act. } \\
\text { (4) }\end{array}$ \\
\hline Interest Rate $(-1)$ & $\begin{array}{l}-0.100 \\
(0.266)\end{array}$ & $\begin{array}{l}-0.038 \\
(0.275)\end{array}$ & $\begin{array}{l}-0.072^{* *} \\
(0.034)\end{array}$ & $\begin{array}{l}-0.039^{* *} \\
(0.020)\end{array}$ \\
\hline Interest Rate U.S. (-1) & $\begin{array}{l}0.548 \\
(0.336)\end{array}$ & $\begin{array}{l}0.696^{* *} \\
(0.347)\end{array}$ & $\begin{array}{l}-0.050 \\
(0.067)\end{array}$ & $\begin{array}{l}-0.033 \\
(0.087)\end{array}$ \\
\hline
\end{tabular}

Notes: Standard errors in parenthesis. $*, * *, * *$ significant at $10 \%, 5 \%, 1 \%$, respectively. Period: $1990 \mathrm{q} 1: 2015 \mathrm{q} 4$. The real interest rate for developed small open economies is the short-term 3-month interest rate from MEI-OECD; the real interest rate for emerging markets is computed as the U.S. Tbill + EMBI GLOBAL. EMs: Argentina, Bulgaria, Chile, Czech Republic, Hungary, Indonesia, Iran, Korea, Malaysia, Mexico, Nigeria, Peru, South Africa, Taiwan, Thailand, Tunisia, Turkey and Ukraine. DOEs: Australia, Austria, Belgium,

Canada, Denmark, Finland, France, Ireland, Italy, Netherlands, Norway, Portugal, Spain, Sweden, and Switzerland.

Table B.5: Emerging Markets: Sectoral Output and Credit Relationship-PMG

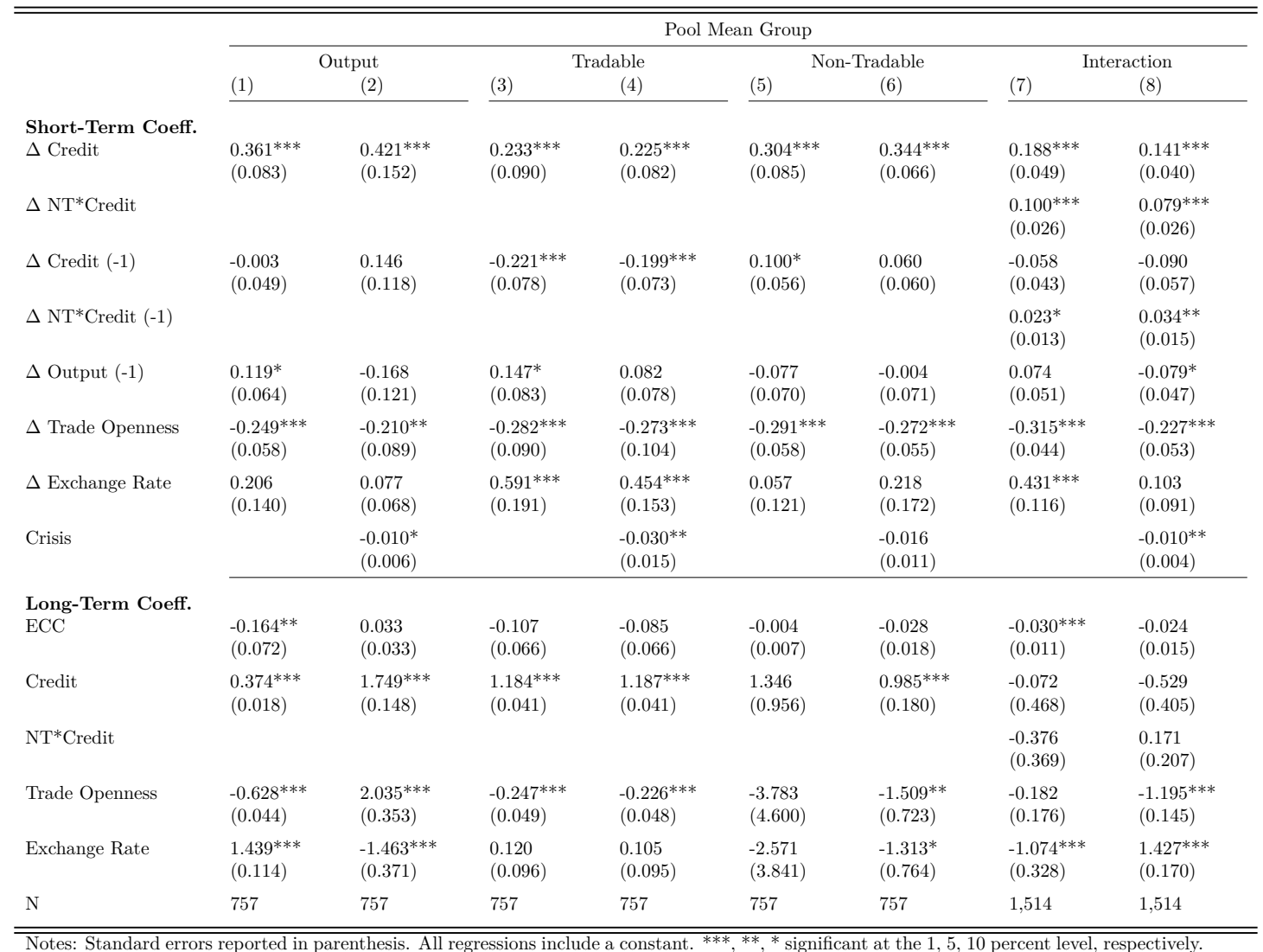




\section{Appendix C Data}

\section{Emerging Markets}

\section{Argentina}

Output. Output data comes from the INDEC (National Institute of Statistic and Census). The data spans between 1993q1:2015q2. Tradable output is computed as the sum of primary activities (agriculture, fishing, and mining) and manufacturing. Non-tradable output includes: electricity, gas, water supply, construction, wholesale and retail trade, hotels and food services activities, transport and communication, finance and real estate, public administration, education, health, and other private services. Credit. The data is provided by the Central Bank of Argentina, and spans from 1992q1:2015q4. Tradable credit includes loans to primary production and manufacturing. Non-tradable credit includes: electricity, gas, water supply, construction, wholesale and retail trade, hotels and food services activities, transport and communication, financial and real estate, public administration, education, health, and other private services.

\section{Brazil}

Output. The data is provided by IBGE-Brazilian Institute of Geography and Statistics, and spans between 1996Q1:2015Q3. Tradable activities include agriculture and manufacturing. Non-tradable activities include all services. Credit. The data is obtained from the Central Bank of Brazil, and spans between 2012Q1:2015Q4. Tradable activities include primary activities (agriculture and mining) and manufacturing. Non-tradable activities include all service activities..

\section{Bulgaria}

Output. Output series are provided by the National Statistical Institute of Bulgaria for the period 1991q1:2015q4. Tradable output includes agriculture, fishing, mining, manufacturing and energy. Non-tradable output includes: construction, wholesale and retail trade, transportation, hotels and food services activities, information and communication, finance, real estate activities, professional activities, public administration, education, health and arts. Credit. The data comes from the National Bank of Bulgaria, and covers 2005q4:2015q4. Tradable activities include primary activities (agriculture and mining) and manufacturing. Non-tradable activities include: electricity, gas, water supply, construction, wholesale and retail trade, hotels and food services activities, transport and storage, information and communication, financial and real estate, public administration, education, health, arts, and other private services. 


\section{Chile}

Output. Data comes from the Central Bank of Chile, and spans from 1996Q1:2015Q4. Tradable activities include agriculture, fishing, mining and manufacturing. Non-tradable activities cover energy, construction, wholesale, transport, communication, finance, personal services, real estate, and public administration. Credit. Data comes from Central Bank of Chile for the period 2005Q1:2015Q4. Tradable activities include agriculture, mining and manufacturing. Non-tradable activities include energy, construction, wholesale, transport, communication, finance, personal services, real estate, and public administration.

\section{Czech Republic}

Output. Data comes from the Czech Statistical Office, and spans from 1995Q1 to 2015Q4. Tradable output is computed as a sum of agriculture, fishing, mining, manufacturing and utilities. Non-tradable output includes construction, wholesale and retail activities, hotel and food services, transport, storage, communication, financial and real estate activities, public administration, education, health and other private services. Credit. Credit data is provided by the Czech National Bank and ranges from 2000Q1:2015Q4. Tradable credit is a sum of agriculture, mining and manufacturing. Non-tradable credit includes electricity, gas, water supply, construction, wholesale and retail activities, transportation and storage, accommodation and food service, financial and real estate activities, professional activities, public administration, arts, and other private sector activities.

\section{Hungary}

Output. Output data is provided by the Central Statistics Office of Hungary, and spans from 1995Q1:2015Q4. Tradable output includes agriculture, forestry and fishing, mining and quarrying, manufacturing, electricity, gas, steam and air conditioning supply, water supply, sewerage, waste management and remediation activities. Non tradable activities are construction, wholesale and retail trade, repair of motor vehicles and motorcycles, accommodation and food service activities, transportation and storage, information and communication, financial and insurance activities, real estate activities, professional, scientific and technical activities, administrative and support service activities, public administration and defense, compulsory social security, education, human health and social work activities, arts, entertainment and recreation, and repair of household goods and other services. Credit. Data is obtained from the Central Bank of Hungary, and spans from 1995Q4: 2015Q4. Tradable credit is computed as a sum of agriculture, forestry, hunting, fishing, mining and manufacturing. Non tradable credit includes electricity, gas, water supply and sewerage, construction, trade and repair of motor vehicles, accommoda- 
tion and food services, information and communication, transport and storage, financial activities, real estate, professional and other activities.

\section{Indonesia}

Output. Data comes from from the Central Bank of Republic of Indonesia, and covers from 1990Q1 to 2014Q3. Tradable output is a sum of agriculture, mining and manufacturing. Non-tradable output includes electricity, gas, water supply, construction, trade, hotels, transport and communication, financial and real state, and other services. Credit. Data is obtained Central Bank of Republic of Indonesia, and spans from 2002Q1:2015Q4. Tradable activities include agriculture, mining and manufacturing. Non-tradable credit are electricity, gas, water supply, construction, trade, hotels, transport and communication, financial and real state, and other services.

\section{Iran}

Output. Output data is provided by the Economic Research and Policy Department, and covers 1990Q1:2010Q4. Tradable output is a sum of agriculture, mining and manufacturing. Non tradable output includes electricity, gas, and water, construction, trade, hotels and restaurants, transportation, communication, real estate, public services, and other private services. Credit. Credit data is obtained from the Economic Research and Policy Department, and spans from 1998Q4:2012Q4. Tradable activities include agriculture and manufacturing. Non tradable activities include construction, trade and other services.

\section{Korea}

Output. Data for output is provided by the Korean Statistical Information Service, and ranges from 1993Q1 to 2015Q3. Tradable output comprises of agriculture, mining and manufacturing. Non tradable activities include electricity, gas, water supply, construction, wholesale and retail, transportation, finance, real state, information and communication, business activities, public administration, education, health and culture services. Credit. Credit data is provided by the Korean Statistical Information Services, and spans from 1998Q3: 2015Q4. Tradable activities include agriculture and manufacturing. Non tradable activities are electricity, gas, water, construction, wholesale, transportation, hotels, information, finance, real estate, professional, business, education, health, and public services in the first definition.

\section{Malaysia}

Output. Data is provided by the Department of Statistics of Malaysia, and spans from 2010Q1:205Q4. Tradable output includes agriculture, mining and manufacturing. Non 
tradable activities include electricity, gas, water, construction, wholesale and retail, hotels and food services, transport, financial and real estate, and government services.

\section{Mexico}

Output. Output data is obtained from the National Institute of Statistics and Geography (INEGI), and spans from 1993Q1:2015Q4. Tradable activities include agriculture, mining and manufacturing. Non-tradable activities include electricity, construction, trade, transportation, information and communication, finance, real estate, professional activities, business, education, health, cultural, hotels, other private services, and government services. Credit. Data is provided by the Central Bank of Mexico, and cover the period 1994Q1: 2015Q4. Tradable activities include food products, beverage and tobacco, textiles, clothing and leather industry, metal products, machinery and equipment, and basic metal. Non-tradable activities include construction, services, wholesale and retail, and other services.

\section{Nigeria}

Output. Output series are obtained from the Central Bank of Nigeria, and range from 1990Q1: 2013Q4. Tradable activities include agriculture and industry. Non tradable activities include construction, wholesale and retail activities, transport, communication, utilities, hotel and food service activities, finance, real estate, government (health and education), and other services.

\section{Peru.}

Output. The Central Reserve Bank of Peru provides data information on output, which spans between 1990Q1:2015Q4. Tradable output is computed as a sum of primary activities and manufacturing. Non-tradable output includes electricity, water, construction, commerce, services. Credit. Data comes from the Superintendent of Banking and Insurance of the Republic of Peru, and spans between 1997Q1: 2015Q4. Tradable activities include agriculture, fishing, minerals and manufacturing. Non-tradable activities include electricity, water supply, gas, construction, wholesale and retail, hotels, transport, finance, real estate, public administration, education, health, and other private services.

\section{Philippines}

Output. Data is provided by the Philippines Statistical Authority, and spans between 1990Q1:2010Q4. Tradable activities include agriculture, fishing and industry. Non-tradable activities include all contracted services. Credit. Data coms from the Central Bank of Philippines, and ranges from 1999Q1 to 2015Q4. Tradable activities are agriculture, fish- 
ing, mining and manufacturing. Non-tradable activities include electricity, gas, water supply, construction, wholesale and retail, hotel and food services, transportation and storage, finance, real estate, public administration, education, health, and other services.

\section{South Africa}

Output. The data is obtained from the South African Reserve Bank, and spans between 1990Q2:2015Q4. Tradable output is computed as a sum of agriculture, mining and manufacturing. Non-tradable output includes electricity, gas, water, construction, wholesale and retail activities, hotels and food services, transport, storage and communication, finance and real estate, personal services, general government services.

\section{Taiwan}

Output. Data comes from the National Statistics Department, Republic of China, and ranges from 1990Q1 to 2015Q4. Tradable activities include agriculture, fishing, mining and manufacturing. Non-tradable activities include electricity, gas, water supply, construction, wholesale and retail trade, transportation and storage, hotel and food services, information and communication, finance and insurance, real estate, professional, support, public administration, education, health, arts, and other private services. Credit. Data on credit is from the Central Bank of the Republic of China, and spans between 1997Q1:2015Q4. Tradable activities include agriculture, fishing, mining and manufacturing. Non-tradable activities include electricity, gas, water supply, construction, wholesale and retail trade, transport and storage, hotels and food services, information and communication, finance, real estate and other services.

\section{Thailand}

Output. Output data is from the Bank of Thailand, and spans between 1993Q1:2015Q4. Tradable output is computed as a sum of primary activities and manufacturing. Nontradable output includes electricity, gas, water supply, construction, wholesale and retail, hotels and restaurants, transport, financial, real, public administration, education, health, and other private services. Credit. Data comes from the Bank of Thailand, and ranges from 2003Q4:2015Q4. Tradable credit includes primary activities and manufacturing. Non-tradable credit covers electricity, gas and water supply, construction, wholesale and retail, hotels and restaurants, transports, financial intermediation, real estate, public administration, education, health and social work, and other activities.

\section{Tunisia}

Output. Data comes from the National Institute of Tunisia, and spans from 2000Q1 to 
2015Q4. Tradable activities are computed as a sum of agriculture, manufacturing, mining and oil. Non-tradable activities include electricity, gas, water, construction, maintenance, trade, hotel, transport, communications, finance and others services.

\section{Turkey}

Output. Data comes from Turkish Statistical Institute, and spans from 1998Q1 to 2015Q4. Tradable output includes agriculture, mining, fishing and manufacturing. Non-tradable activities are: electricity, gas, water supply, construction, wholesale and retail, transport, hotels and food service activities, information and communication, finance, real estate activities, professional and scientific, administrative support, public administration, education, health, arts, and other private services. Credit. Data on credit is provided by the Central Bank of Turkey, and ranges from 1999Q1 to 2013Q4. Tradable activities are computed as a sum of primary activities and manufacturing. Non-tradable activities include construction, finance, real estate, transport, hotels, education, health, public administration, others private services, retail and wholesale, electricity, gas and water supply.

\section{Ukraine}

Output. The data is obtained from the State Statistics Service of Ukraine, and spans between 2001Q1:2013Q4. Tradable activities are computed as a sum of agriculture, mining and manufacturing. Non-tradable output are electricity, gas and water, construction, wholesale and retail trade, accommodation and food services, transport, information media and telecommunications, financial real estate services, professional, scientific and technical services, administrative and support services, public administration, education, health care and social assistance, arts and recreation services, and other services. Credit. Data comes from the National Bank of Ukraine, and spans from 2002Q4 to 2012Q4. Tradable credit is a sum of agriculture, mining and manufacturing. Non-tradable credit includes

electricity, gas and water, construction, wholesale and retail trade, accommodation and food services, transport, information media and telecommunications, financial real estate services, professional, scientific and technical services, administrative and support services, public administration, education, health care and social assistance, arts and recreation services, and other services. 


\section{Developed Open Economies}

\section{Australia}

Output. Output series are provided by the Australian Bureau of Statistics, and span between 1990Q1:2015Q4. Tradable activities are agriculture, fishing, mining and manufacturing. Non-tradable activities include electricity, gas and water, construction, wholesale and retail trade, accommodation and food services, transport, information media and telecommunications, financial real estate services, professional, scientific and technical services, administrative and support services, public administration, education, health care and social assistance, arts and recreation services and other services.

\section{Canada}

Output. Output data is obtained from Statistics Canada, and spans between 1997Q1:2014Q4. Tradable activities are the sum of agriculture, fishing, mining and manufacturing. Nontradable activities are electricity, gas and water, construction, wholesale and retail trade, accommodation and food services, transport, information media and telecommunications, financial real estate services, professional, scientific and technical services, administrative and support services, public administration, education, health care and social assistance, arts and recreation services and other services.

\section{Austria, Belgium, Denmark, Finland, France, Ireland, Italy, Netherlands, Nor-} way, Portugal, Spain, Sweden and Switzerland

Output. Output data is provided by the ESA-European System of Accounts, and ranges from 1995Q1 to 2015Q4. Tradable activities include agriculture, industry and manufacturing. Non-tradable activities include construction, wholesale and retail trade, transport, accommodation and food service activities, information and communication, financial and insurance services, real estate activities, professional and technical activities, administrative activities, public administration and defense, education, social work, arts, entertainment and recreation, other services, and activities of household and extra territorial bodies. 